\title{
2014 iAREA campaign on aerosol in Spitsbergen - Part 1: Study of physical and chemical properties
}

\author{
J. Lisok ${ }^{\text {a, }}{ }^{*}$, K.M. Markowicz ${ }^{\text {a }}$, C. Ritter ${ }^{\text {b }}$, P. Makuch ${ }^{\text {c }}$, T. Petelski ${ }^{c}$, M. Chilinski a \\ J.W. Kaminski ${ }^{\text {f }}$, S. Becagli ${ }^{\mathrm{d}}$, R. Traversi ${ }^{\mathrm{d}}$, R. Udisti ${ }^{\mathrm{d}}$, A. Rozwadowska ${ }^{\mathrm{c}}$, M. Jefimow ${ }^{\mathrm{e}}$, \\ P. Markuszewski c, g, R. Neuber ${ }^{\text {b }}$, P. Pakszys ${ }^{\text {c, g }}$, I.S. Stachlewska a , J. Struzewska e, \\ T. Zielinski ${ }^{\text {c, g }}$
}

a Institute of Geophysics, Faculty of Physics, University of Warsaw, Warsaw, Poland

${ }^{\mathrm{b}}$ Alfred Wegener Institute, Helmholtz Centre for Polar and Marine Research, Potsdam, Germany

${ }^{\mathrm{c}}$ Institute of Oceanology, Polish Academy of Sciences, Sopot, Poland

${ }^{\mathrm{d}}$ Department of Chemistry, University of Florence, Sesto Fiorentino, Italy

${ }^{\mathrm{e}}$ Faculty of Environmental Engineering, Warsaw University of Technology, Poland

${ }^{\mathrm{f}}$ EcoForecast Foundation, Warsaw, Poland

${ }^{g}$ Centre for Polar Studies KNOW (Leading National Research Centre), Sosnowiec, Poland

\section{H I G H L I G H T S}

- Complex studies on aerosol properties during spring on Spitsbergen are presented.

- In-situ, remote sensing instruments and model results are included in the campaign.

- Scattering properties were found to be correlated with wind speed.

- Some sea-spray advections are detected and described in detail.

- Spring 2014 seems to be relatively clean with only a small load of Arctic Haze events.

\section{A R T I C L E I N F O}

\section{Article history:}

Received 10 November 2015

Received in revised form

24 May 2016

Accepted 26 May 2016

Available online 28 May 2016

\section{Keywords:}

Single scattering properties

Chemical composition

Long-range transport

Arctic

\begin{abstract}
A B S T R A C T
This paper presents the results of measurements of aerosol physical and chemical properties during iAREA2014 campaign that took place on Svalbard between 15th of Mar and 4th of May 2014. With respect to field area, the experiment consisted of two sites: Ny-Ålesund $\left(78^{\circ} 55^{\prime} \mathrm{N}, 11^{\circ} 56^{\prime} \mathrm{E}\right)$ and Longyearbyen $\left(78^{\circ} 13^{\prime} \mathrm{N}, 15^{\circ} 33^{\prime} \mathrm{E}\right)$ with further integration of Aerosol Robotic Network (AERONET) station in Hornsund $\left(77^{\circ} 00^{\prime} \mathrm{N}, 15^{\circ} 33^{\prime} \mathrm{E}\right)$. The subject of this study is to investigate the in-situ, passive and active remote sensing observations as well as numerical simulations to describe the temporal variability of aerosol single-scattering properties during spring season on Spitsbergen. The retrieval of the data indicates several event days with enhanced single-scattering properties due to the existence of sulphate and additional sea-salt load in the atmosphere which is possibly caused by relatively high wind speed. Optical results were confirmed by numerical simulations made by the GEM-AQ model and by chemical observations that indicated up to $45 \%$ contribution of the sea-salt to a $\mathrm{PM}_{10}$ total aerosol mass concentration. An agreement between the in-situ optical and microphysical properties was found, namely: the positive correlation between aerosol scattering coefficient measured by the nephelometer and effective radius obtained from laser aerosol spectrometer as well as negative correlation between aerosol scattering coefficient and the Ångstrom exponent indicated that slightly larger particles dominated during special events. The in-situ surface observations do not show any significant enhancement of the absorption coefficient as well as the black carbon concentration which might occur during spring. All of extensive single-scattering properties indicate a diurnal cycle in Longyearbyen, where 21:00-5:00 data stays at the background level, however increasing during the day by the factor of 3-4. It is considered to be highly connected with local emissions originating in combustion, traffic and harbour activities. On the other hand, no daily fluctuations in $\mathrm{Ny}$-Ålesund are observed. Mean values in $\mathrm{Ny}-$ Ålesund are equal to 8.2, $0.8 \mathrm{Mm}^{-1}$ and $103 \mathrm{ng} / \mathrm{m}^{3}$ for scattering, absorption coefficients and black carbon concentration;
\end{abstract}

\footnotetext{
* Corresponding author.

E-mail address: jlisok@igf.fuw.edu.pl (J. Lisok).
} 
however in Longyearbyen (only data from 21:00-05:00 UTC) they reach 7.9, $0.6 \mathrm{Mm}^{-1}$ as well as $83 \mathrm{ng} /$ $\mathrm{m}^{3}$ respectively. Overall, the spring 2014 was considerably clean and sea-salt was the major aerosol component.

๑) 2016 Elsevier Ltd. All rights reserved.

\section{Introduction}

Aerosol optical and chemical properties measurements have become of a great importance due to their high impact on climate change manifesting the most in sensitive Arctic regions (Engvall et al., 2008). Regarding model's results, the annual mean temperature is expected to increase with the highest factor over polar latitudes in a few decades (Graversen et al., 2008; Hassol, 2005). Despite the fact of Arctic being relatively free of human-derived emission sources, many events with increased aerosol optical properties have been measured and studied. According to an aerosol production the geographical distribution of semi-stationary pressure centres in the northern hemisphere determines Svalbard archipelago the most pristine site of the Arctic due to prevailing north advections of particles and also due to the gulf stream, which transports warm and moist air mass with intensive aerosol wet deposition processes. Hence, a simultaneous separation of air mass transport from North America by Icelandic Low indicates Eurasia the only occasional southern source area for long-range transport of pollutants (Stone et al., 2014). However, Bazzano et al., 2015, demonstrated that the source areas for anthropogenic pollutants are seasonally characterized, with main input from Eurasia in spring and from Canada-USA in summer. The contribution to pollutant emission of metallurgical industry as well as coal mining in Russian Arctic together with local domestic and traffic combustion underestimates the total anthropogenic aerosol load exiting in Polar Regions. Hence, it indicates considering long-range transport a major source of sulphate, nitrates as well as dust and black carbon (BC) (Heintzenberg et al., 1981; Rozwadowska et al., 2010). Regarding natural sources during vegetation season an organic carbon emissions combined with methane are observed (Guo et al., 2007). Hence, a recent winter reduction in sea-ice extent underlying the climate change mechanisms reveals a new ocean areas being under influence of weather conditions (Parkinson and Cavalieri, 2012). Furthermore, within the last decade an enhancement of events initiated by a sea-spray production over Arctic Ocean during winter-spring season was observed (Parkinson and Cavalieri, 2012; Zábori et al., 2012). Moreover, volcanic activity with stratospheric aerosol loading has a high impact on aerosol single scattering properties in Arctic (Tomasi et al., 2012). Since 1970s a long term trend of background aerosol optical depth (AOD) values seems to vary over time. In 1970s-1980s AOD decreased appreciably as a result of global dimming decay (Tomasi et al., 2012). According to Tomasi et al. (2012) during 1990-2010 AOD variability did not indicate any trend, however regarding studies of Stone et al. (2014) a small positive increase of AOD might be observed since 2000s.

The annual load of aerosols in Arctic varies over seasons altering the values of single scattering properties (Tomasi et al., 2015). The maximum occurs during winter-spring season where a three decade long term mean values of Aerosol Optical Depth (AOD) for $500 \mathrm{~nm}$ in $\mathrm{Ny}$-Ålesund reach maximum equal to $0.07-0.09$ and Ångstrom exponent $(\mathrm{AE})$ being between 1.3 and 1.5 (Tomasi et al., 2015). Further investigation of Tomasi et al. (2012) indicates fine mode of water-soluble and sea-salt as well as sea-salt coarse mode to have the largest impact on aerosol optical properties.
However, the lowest level of long term measurements might be observed during summer-autumn season referring to as background values (Stone et al., 2014) where AOD decreases to $0.02-0.05$ and AE stays at the level of 1.3 respectively (Tomasi et al., 2012). At this time the prevailing particles consist of mineral dust and water-soluble fine mode as well as sea-salt coarse mode. However, events, the most affecting optical measurements during summer, contain combustion nuclei mode and accumulation mode both originating from biomass burning events (Tomasi et al., 2015).

A number of remote sensing Lidar measurements of aerosol optical properties vertical profiles have been studied in Tomasi et al. (2015) for 2012-2013 indicating an annual variability of backscatter coefficient with the maximum value occurring during winter-spring season. Hence, the vertical structure seems to consist of two layers with enhanced aerosol properties. The first one is included within the atmospheric boundary layer $(0-1.5 \mathrm{~km})$ second one occurs between 2 and $4 \mathrm{~km}$ existing due to a long range transport (Tomasi et al., 2015).

A closure study of aerosol properties in the Arctic requires solving the discrepancies in measurement techniques, spatial and temporal resolution as well as hygroscopic growth of aerosols. Considering remote sensing and in-situ instruments, they apply optical or physical and chemical properties respectively, resulting in different quantities of measurements, which might be compared only after transformation by means of theoretical equations or empirical parameterisations of the data (Mazzola et al., 2012; Tesche et al., 2014). Furthermore, in-situ measurements often reduce relative humidity $(\mathrm{RH})$ inside the chamber to dry conditions (10-30\% RH), whereas remote-sensing instruments work in ambient air. Hence, in order to analyze both data sets, a model assumption is required to quantify the size of particles after drying, otherwise in-situ data should be converted into ambient conditions (Tang, 1996; Tang and Munkelwitz, 1994; Zieger et al., 2013). What is more, data need to be equalized to one temporal resolution to make certain they both observe the same air mass by means of averaging (Tesche et al., 2014).

The following article contains the results from the first of two field campaigns provided within the iAREA (Impact of Absorbing Aerosols on Radiative Forcing in the European Arctic) research program, which took place between 16.03 and 04.05.2014 in Ny-Ålesund and Longyearbyen on Spitsbergen. Section 2 includes description of research sites, instrumentation and model used during the field campaign. Section 3 shows the overview of temporal variability of measured and simulated aerosol optical and chemical properties as well as a more detailed description of sea-spray events, which occurred during the campaign. In Section 4 we discuss the case studies while the conclusions of this article are summarized in Section 5.

\section{Field area and instruments}

\subsection{Field area}

The field campaign was carried out in $\mathrm{Ny}-$ Ålesund $\left(78^{\circ} 55^{\prime} \mathrm{N}\right.$, $\left.11^{\circ} 56^{\prime} \mathrm{E}\right)$ and Longyearbyen $\left(78^{\circ} 13^{\prime} \mathrm{N}, 15^{\circ} 33^{\prime} \mathrm{E}\right)$ - towns located on Spitsbergen Island, which belongs to Svalbard Archipelago (Fig. 1b). 
Moreover, we used data from Polish Polar Station in Hornsund $\left(77^{\circ} 00^{\prime} \mathrm{N}, 15^{\circ} 33^{\prime} \mathrm{E}\right)$ situated in the southern part of Spitsbergen (Fig. 1a). Measurements provided in the Island are mostly free of local emissions regarding poor representation of habited areas. Therefore, Arctic Haze, the most important air pollution caused by long-range transport of aerosol, should be principally well observable on the island. Ny-Ålesund represents a small scientific town situated in the north-western part of Spitsbergen abutted with Arctic Ocean (through the Kongsfjorden fiord on the north-east side of the town. Hence, it is surrounded by mountains at the remaining three sides, what might induce some local effects. All the in-situ instruments were put in the Gruvebadet observatory (supervised by the Italian staff), located $800 \mathrm{~m}$ south-west from Ny-Ålesund. Possibly, some sources of local contamination including small diesel-filled stations (NNE direction from aerosol in-situ measurements in Gruvebadet) and traffic such as snowmobiles, ships and airplanes (NNW direction from Gruvebadet) may contribute to some local pollution.

However, further remote sensing Lidar as well as Microtops II measurements were provided on a platform of Alfred Wegener Institute (AWI) observatory. Longyearbyen, located about $100 \mathrm{~km}$ south-east from Ny-Ålesund (Fig. 1a), is occupied by 1.8 thousand people, so it represents a more polluted region due to local emissions from coal power plant, coal mining, harbour activity, domestic heating and vehicular traffic. It is located at the foreland of the Longyearbreen glacier valley, surrounded by the mountains $500 \mathrm{~m}$ a.s.l. high, next to the Adventfjorden Bay (NE). Measurements were provided at the lowest part of the town, $100 \mathrm{~m}$ from the fiord shore. The last included data was provided within the Aerosol Robotic Network (AERONET), taken from Polish Polar Station in Hornsund located in southern part of Spitsbergen (Fig. 1a) on a foreground of Hansbreen glacier. Hornsund station is surrounded by the Isbjörnhamna, the ocean fiord bay from the southern site, otherwise by the mountains. This station was considered a reference site due to lack of habited areas, suppressing anthropogenic emission of pollutants in the direct surrounding environment.

\subsection{Instruments}

During the campaign aerosol single scattering properties were provided with a few instruments that might be generally referred to as in-situ and remote sensing measurements. Regarding the first group: nephelometers, photoacoustic extinctiometers, as well as particle counters were operating (Table 1). Furthermore, we included Lidar and sun photometers data into the group of remote-sensing measurements.

Aerosol scattering properties in Ny-Ålesund were measured by nephelometer 3563 from TSI operating on 3 wavelengths with 1 min resolution (Anderson et al., 1996). Regarding Longyearbyen polar nephelometer Aurora 4000 (Ecotech company) measurements of scattering coefficient were provided in 3 wavelengths with 5 min resolution (Arnott et al., 2005). The 3563 TSI nephelometer uses the halogen flash lamp while Aurora 4000 the LED array. The electrical drive current of each LED was adjusted, so that the angular intensity distribution of the light source was nearly a Lambertian radiation distribution (Müller et al., 2011). It is worth emphasis the LED light sources generates only fraction of the heat developed by halogen flash lamps in traditional nephelometers. Truncation angles for the TSI 3563 were given in Anderson et al. (1996) and reported to be $7^{\circ}$ and $170^{\circ}$ while for Aurora 4000 were determined to be $10^{\circ}$ and $171^{\circ}$. Correction for truncation angles depends on aerosol size distribution and usually is done based on the AE (Anderson and Ogren, 1998; Müller et al., 2011). Furthermore, the instruments were calibrated by $\mathrm{CO}_{2}$ before and after the campaign. The zero check calibrations were performed automatically every 10 min and $24 \mathrm{~h}$ for both TSI and Aurora 4000 nephelometers respectively. Given the methodology proposed by Anderson and Ogren (1998) and Müller et al. (2011) nephelometer data was processed through correction of non-Lambertian illumination and the angular truncation contributes.

One wavelength Photoacoustic Extinctiometer (PAX) is a new instrument from Droplet Measurement Technologies company measuring extinction coefficient and its components as well as the single scattering albedo (SSA) and BC mass concentration (Kok et al., 2010). It uses photoacoustics method to retrieve absorption, by detection of pressure waves initiated by emission of energy from absorbing particle. The construction of scattering chamber is based on nephelometer technique. The detection limit for $60 \mathrm{~s}$ averaging for absorption and scattering coefficient is less than $0.25 \mathrm{Mm}^{-1}$ $(870 \mathrm{~nm})$. The detector measures scattering light between $6^{\circ}$ and $174^{\circ}$. Two instruments with 532 and $870 \mathrm{~nm}$ were installed in Gruvebadet observatory in Ny-Ålesund and Longyearbyen operating with $5 \mathrm{~min}$ resolution. PAX calibrations were provided 6 months before the campaign in the factory.

Furthermore, Gruvebadet site was equipped with three particle counters: one installed only for campaign period (LAS) and further two (SMPS and APS) for continuous measurements from Mar to Sep. Regarding small particles, Laser Aerosol Spectrometer (3340) from TSI was used to detect concentration of aerosols within a range of $0.09-7.5 \mu \mathrm{m}$ and $1 \mathrm{~min}$ averaging. LAS measures the extinction of laser light intensity with respect to scattering to achieve size of particles.

Furthermore, we obtained data from two particle sizers, namely Scanning Mobility Particle Sizer (TSI SMPS model 3034), making use of the differential electro-mobility of particles and Aerodynamic Particle Sizer (TSI APS), measuring the actual aerodynamic diameter of single particles by the time of flight between two consecutive laser beams. TSI-SMPS and TSI-APS instruments were certified by the manufacturer. The calibration system meets ISO-9001:2000, Quality Management Systems Requirements and complies with ISO 10012:2003, Quality Assurance Requirements for Measuring Equipment. The SMPS-APS integrated system was able to continuously collect one synchronized size spectrum (106 size-classes) every $10 \mathrm{~min}$. SMPS provides a 54 size-classes spectrum in the range of $10-487 \mathrm{~nm}$, as an average of 3 consecutive 3-min measurements; APS gives a 52 size-classes spectrum in the range of $0.5-20 \mu \mathrm{m}$, as an average of 9 consecutive 1 min measurements, one minute stop allows the two devices synchronization.

Aerosol samples were continuously collected from 31 Mar to 18 Apr with two sampling devices: $\mathrm{PM}_{10}$ (particle matter collected with a $10 \mu \mathrm{m}$ cut-off head) and 4 -stage impactors. PM $_{10}$ was daily collected (00:01-23:59 UTC) on Teflon filters (Pall, $47 \mathrm{~mm}$ diameter, $2 \mu \mathrm{m}$ nominal porosity) by a TCR TECORA sequential aerosol sampler. The sampling head was designed according to EN-12341 European rules and operated at $38.3 \mathrm{~L} \mathrm{~min}^{-1}$ (actual volume), corresponding to a $24 \mathrm{~h}$ volume of about $55 \mathrm{~m}^{3}$. $\mathrm{PM}_{10}$ mass was measured by weighing the filters with a microbalance $(0.01 \mathrm{mg}$ sensitivity), before and after exposure. The filters were conditioned at low humidity (silica gel) and temperature $\left(25 \pm 1{ }^{\circ} \mathrm{C}\right)$ for at least $24 \mathrm{~h}$ prior to weighing. A data loss occurred in the period 19th Apr -4 th May by a system failure.

Size-segregated aerosol samples were collected by using a 4-stage Dekati impactor $(>10,2.5-10,1-2.5,<1 \mu \mathrm{m})$, operating at $29 \mathrm{~L} \mathrm{~min}^{-1}$. In order to collect a sufficient aerosol amount for the chemical analysis, 4-day sampling time was chosen. Polycarbonate membranes $(0.1 \mu \mathrm{m}$ nominal porosity) were used for collecting the aerosol in the first three size classes (from $>10$ to $1 \mu \mathrm{m}$ ), while the sub-micrometric fraction was collected on a backup Teflon filter. Filters were handled under class 100 laminar flow hoods in order to 


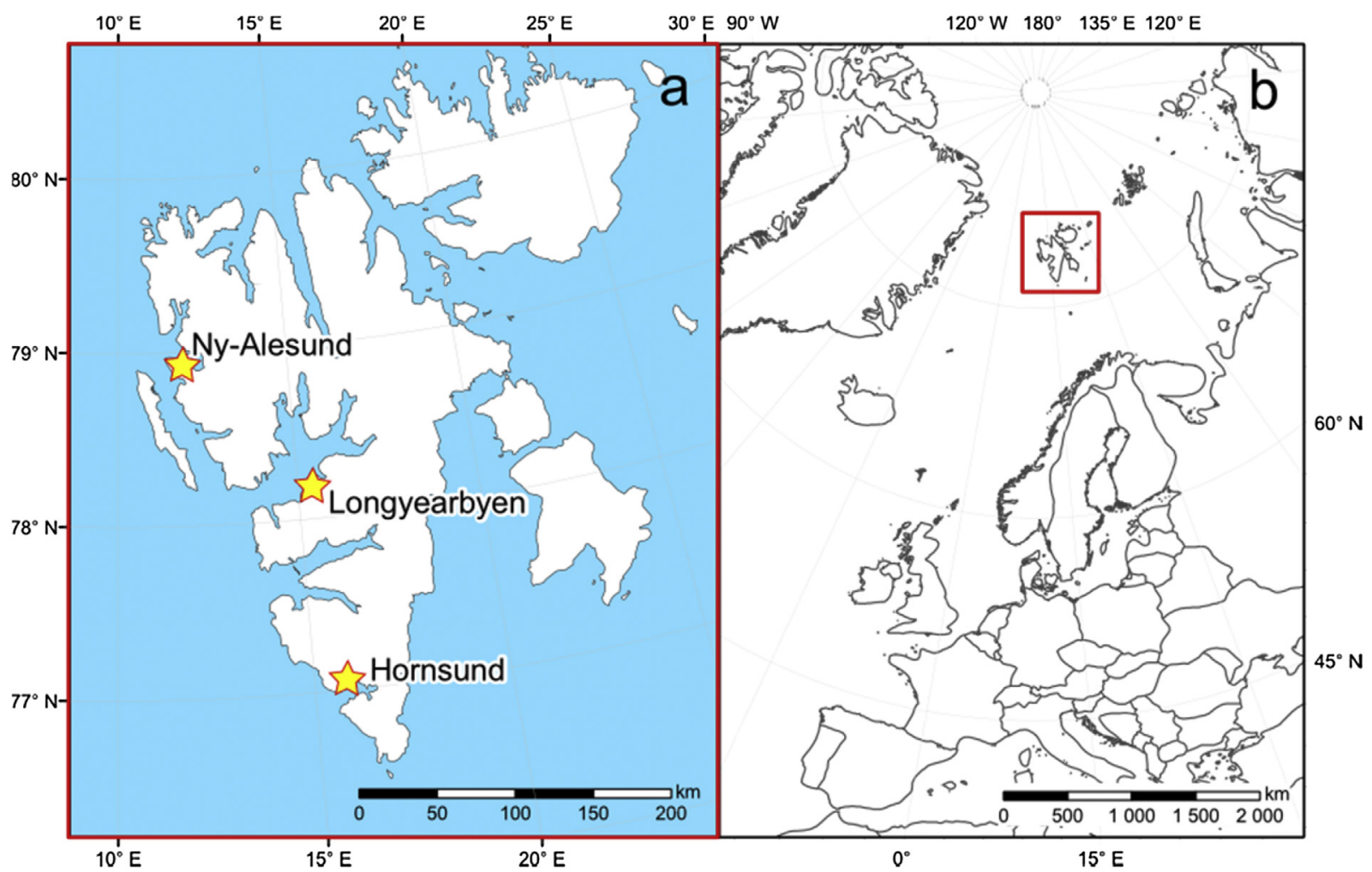

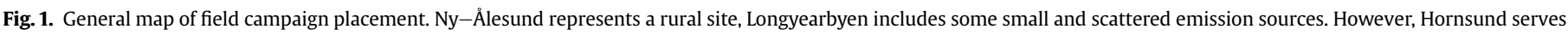
as a reference station.

Table 1

Instruments measuring optical properties of the atmosphere during iAREA spring campaign.

\begin{tabular}{|c|c|c|c|c|c|}
\hline Name & $\lambda[\mathrm{nm}]$ & Property & $\Delta \mathrm{t}$ & Period & Station \\
\hline Polar Nephelometer Aurora $4000^{\mathrm{a}}$ & $450,525,635$ & $\sigma_{\mathrm{SCAT}}, \mathrm{AE}$ & $5 \mathrm{~min}$ & $20 \mathrm{Mar}-13 \mathrm{Apr}$ & Longyearbyen \\
\hline Nephelometer $3563^{\mathrm{b}}$ & $450,550,700$ & $\sigma_{\mathrm{SCAT}} \mathrm{AE}$ & $1 \mathrm{~min}$ & 26 Mar - 04 May & Ny-Ålesund \\
\hline \multirow[t]{2}{*}{ Photo-Acoustics Extinctiometer $(\mathrm{PAX})^{\mathrm{c}}$} & 532 & $\sigma_{\mathrm{EXT}}, \sigma_{\mathrm{ABS}}, \sigma_{\mathrm{SCAT}}$ & $5 \mathrm{~min}$ & 26 Mar - 04 May & Ny-Ålesund \\
\hline & 532 & SSA, BC & & $20 \mathrm{Mar}-13 \mathrm{Apr}$ & Longyearbyen \\
\hline \multirow[t]{3}{*}{ Microtops II Sun Photometer ${ }^{\mathrm{d}}$} & 5 of: $340,380,440$ & AOD & $<1 \min$ & Irregular & Longyearbyen \\
\hline & $500,675,870$ & $\mathrm{AE}$ & & & Ny-Ålesund \\
\hline & 1020 & & & & \\
\hline \multirow[t]{2}{*}{ AWI Aerosol Raman Lidar KARL ${ }^{\mathrm{e}}$} & $355,387,407,532$ & $\beta$ & $2 \min$ & Irregular & Ny-Ålesund \\
\hline & $607,660,1064$ & $\sigma_{\mathrm{EXT}}$ & & & \\
\hline \multirow[t]{4}{*}{ Sun photometer CIMEL ${ }^{\mathrm{f}}$} & $340,380,412,490$ & AOD & $<1 \min$ & Irregular & Hornsund \\
\hline & $500,531,551,555$ & $\mathrm{AE}$ & & & \\
\hline & $667,675,870$ & & & & \\
\hline & 1020,1640 & & & & \\
\hline Laser Aerosol Spectrometer (LAS) $3340^{\mathrm{g}}$ & $90-7500$ & Particle conc. & $1 \mathrm{~min}$ & 26 Mar - 04 May & Ny-Ålesund \\
\hline Scanning Mobility Particle Sizer Spectrometer SMPS $3034^{\mathrm{h}}$ & $10-487$ & Particle conc. & $10 \mathrm{~min}$ & 31 Mar - 04 May & Ny-Ålesund \\
\hline Aerodynamic Particle Sizer APS $3321^{\mathrm{i}}$ & $500-20,000$ & Particle conc. & $10 \mathrm{~min}$ & 31 Mar - 04 May & Ny-Ålesund \\
\hline \multirow[t]{5}{*}{ SP1A Sun Photometer ${ }^{j}$} & $369,381.1,412.9$ & AOD & $1 \mathrm{~min}$ & Irregular & Ny-Ålesund \\
\hline & $499.8,609.8$ & $\mathrm{AE}$ & & & \\
\hline & $673.8,778.5$ & & & & \\
\hline & $859.8,944.8$ & & & & \\
\hline & 1022.9 & & & & \\
\hline
\end{tabular}

a Arnott et al. (2005).

b Anderson et al. (1996).

c Kok et al. (2010).

d Morys et al. (2001).

e Hoffmann et al. (2010).

f Holben et al. (1998).

g Simon and Duquenne (2013).

h Hogrefe et al. (2006).

i Peters and Leith (2003).

j Herber et al. (2002). 
minimize sample contamination. One half of each $\mathrm{PM}_{10}$ Teflon filter was extracted in about $10 \mathrm{ml}$ MilliQ water (accurately evaluated by weighing) by ultrasonic bath for 20 min for ionic content determination. Inorganic anions and cations as well as selected organic anions were simultaneously measured by using a three Dionex ion-chromatography system equipped with electrochemical suppression. The sample handling during the IC injection was minimized by using a specifically-designed Flow-Injection Analysis (IC-FIA) device (Morganti et al., 2007). Cations $\left(\mathrm{Na}^{+}, \mathrm{NH}_{4}^{+}, \mathrm{K}^{+}\right.$, $\mathrm{Mg}^{2+}$ and $\mathrm{Ca}^{2+}$ ) were determined by using a Dionex CS12A-4 mm analytical column with $20 \mathrm{mM} \mathrm{H}_{2} \mathrm{SO}_{4}$ eluent. Inorganic anions $\left(\mathrm{Cl}^{-}\right.$, $\mathrm{NO}_{3}^{-}, \mathrm{SO}_{4}^{2-}$ and $\mathrm{C}_{2} \mathrm{O}_{4}^{2-}$ ) were measured by a Dionex AS4A-4 mm analytical column with a $1.8 \mathrm{mM} \mathrm{Na}_{2} \mathrm{CO}_{3} / 1.7 \mathrm{mM} \mathrm{NaHCO} 3$ eluent. $\mathrm{F}^{-}$ and some organic anions (acetate, glycolate, formate and methanesulphonate) were determined by a Dionex AS11 separation column by a gradient elution $\left(0.075 \mathrm{mM}-2.5 \mathrm{mM} \mathrm{Na}_{2} \mathrm{~B}_{4} \mathrm{O}_{7}\right.$ eluent $)$. Six standard calibration curves were daily used for quantification. Further details are reported in Becagli et al., 2011.

Additionally, we retrieved four basic aerosol species from chemical in-situ measurements. Mass of sea-salt can be obtained as follows:

$\mathrm{SS}=3.248 \cdot \mathrm{sSNa}^{+}$

$\mathrm{ssNa}^{+}=\operatorname{totNa}^{+}-0.562 \cdot \mathrm{nssCa}^{2+}$

$\mathrm{nssCa}^{2+}=\operatorname{totCa}^{2+}-0.038 \cdot \mathrm{ssNa}^{+}$

where 0.562 represents the $\mathrm{Na}^{+} / \mathrm{Ca}^{2+}$ weight to weight $(\mathrm{w} / \mathrm{w})$ ratio in the crust (Bowen, 1979) and 0.038 is the $\mathrm{Ca}^{2+} / \mathrm{Na}^{+} \mathrm{w} / \mathrm{w}$ ratio in seawater (Nozaki, 1997). SS, $\mathrm{Na}^{+}$and $\mathrm{Na}^{+}, \mathrm{Ca}^{2+}$ refer to mass of sea-salt, sodium and calcium ions respectively. The prefixes tot, ss, and nss are referred to a total concentration, sea-salt and nonsea-salt contributions to ions.

As we lacked with total crust composition measurements, a mass of mineral dust might be approximated by the following equation as stated by Marconi et al. (2014):

$\mathrm{DU}=10.0 \cdot \mathrm{nssCa}^{2+}$

Nonsea-salt sulphate was retrieved yielding:

$\mathrm{nssSO}_{4}^{2-}=\operatorname{totSO}_{4}^{2-}-0.25 \cdot \mathrm{ssNa}^{+}$

where 0.25 indicates the $\mathrm{SO}_{4}^{2-} / \mathrm{Na}^{+}(\mathrm{w} / \mathrm{w})$ ratio in seawater (Bowen, 1979).

We also calculated secondary inorganic aerosols by summing the concentration of nitrate, nitrite and ammonium. We didn't include, however, $\mathrm{nsSO}_{4}^{2-}$ to the equation due to the importance of this component to determine air mass advection type. Unfortunately, the two latter equations are only appreciable approximations, so significant deviations might occur.

Apart from continuous measurements we additionally analysed remote sensing data provided during clear sky or partly cloudy conditions. One of the active remote sensing instruments of this campaign was the "Koldewey Aerosol Raman Lidar" KARL, located at the atmospheric observatory in Ny-Ålesund. KARL is a Lidar with a Nd:Yag laser, which measures the backscatter coefficient at 3 colours ( $355 \mathrm{~nm}, 532 \mathrm{~nm}, 1064 \mathrm{~nm}$ ), the depolarization and the extinction, via the Raman scattering at $\mathrm{N}_{2}$ molecules, at 2 colours $(355 \mathrm{~nm}, 532 \mathrm{~nm})$. Such a configuration is called $3+2+2^{\prime \prime}$ system. The laser power is approx. $200 \mathrm{~mJ}$ per pulse and colour, and a repetition rate of $50 \mathrm{~Hz}$ is used. The recording telescope has $70 \mathrm{~cm}$ diameter and measurements have been obtained with a field of view of 1.7 mrad. Overlap is completed beyond $900 \mathrm{~m}$ altitude. The maximal resolution of the raw data is $2 \mathrm{~min}$ and $7.5 \mathrm{~m}$. Further details on the system are described in Hoffmann et al., 2010.

Automatic measurements of AOD as well as AE were provided by Alfred Wegener Institute (AWI) in Ny-Ålesund by means of SP1A Sun Photometer from Dr. Schulz and Partner GmbH with a resolution of $1 \mathrm{~min}$. The instrument provides the measurements within 10 spectral channels ranging between 369 and $1022.9 \mathrm{~nm}$ with $1^{\circ}$ field of view. SP1A Sun Photometer is calibrated every year in a relatively pristine mountainous area (i.e. Tenerife, Spain) (Herber et al., 2002). Further AOD and AE data was retrieved manually from four 5-wavelength Microtops II sun photometers from Solar Light Company, which yields direct solar irradiance technique (Morys et al., 2001). Each particular instrument has its own set of spectral channels ranging between 340 and $1020 \mathrm{~nm}$. Measurements were provided in a close neighbourhood with Lidar measurements in Ny-Ålesund and in-situ instruments in Longyearbyen with arbitral time resolution of $15 \mathrm{~min}$. Microtops II calibration was performed in Sep 2013 versus the CIMEL sun photometer at Strzyzow AERONET (Aerosol Robotic Network) station. In addition, we used lev. 2.0 data from Hornsund AERONET station equipped with CIMEL sun photometer (Holben et al., 1998).

Regarding meteorological data, we present the measurements provided by AWI's atmosphere observatory in Ny-Ålesund (temperature, wind speed and wind direction) as well as encoded SYNOP reports from the Ny-Ålesund II WMO station (code 10040) carried out at the airport (precipitation). Furthermore, we used National Climatic Data Center (NCDC) Global Summary of Day (GSOD) database (http://www7.ncdc.noaa.gov/CDO/cdodata.cmd, date of access: 25.06.2015) to obtain climatological long term mean value of precipitation.

\subsection{Model}

During the campaign a daily chemical and weather forecast was provided. The on-line tropospheric chemistry model - GEM-AQ (Kaminski et al., 2008) was used as a computational tool. Aerosols are modeled with a sectional module based on Gong et al. (2003) with 5 aerosols types: sulphate, black carbon, organic carbon, sea-salt and soil dust, size-segregated into 12 logarithmically spaced bins. The aerosol module includes parameterizations of nucleation, condensation, coagulation, sedimentation and dry deposition, in-cloud oxidation of $\mathrm{SO}_{2}$ as well as scavenging and below-cloud scavenging of aerosol species by rain and snow.

The GEM-AQ model was run on the global variable grid with rotated equator and with the resolution of $0.15^{\circ} \times 0.15^{\circ}$ centred over the Svalbard archipelago. Number of grid points was set on the globe to $356 \times 320$ and $200 \times 200$ in the core part. In the vertical, 28 sigma-hybrid layers extending to $10 \mathrm{hPa}$ were used. The simulation was performed from 8th Mar to 10th May 2014, as a set of 72 -h forecasts. The integration time step of $450 \mathrm{~s}$ was used. Emission data were prepared by Norwegian Institute for Air Research (NILU) in the frame of ECLIPSE project (Klimont et al., 2013). The model was validated in a number of experiments. In AQMEII-1 intercomparison the GEM-AQ showed a very good agreement with measurements as compared to other models (Struzewska et al., 2015). The emission inventory was provided on the global grid with the resolution of $0.5^{\circ} \times 0.5^{\circ}$. Anthropogenic emissions were available as annual average for the base year 2010, while biomass burning and ship emissions were estimated as monthly averages. Due to some overestimation of $\mathrm{SO}_{\mathrm{x}}$ and $\mathrm{OC} / \mathrm{BC}$ in emission inventory databases for Europe, some results in remote regions such as Arctic, might be affected. It can lead to higher concentration of species in a forecast results.

Finally, for event days $144 \mathrm{~h}$ back trajectories were obtained 
from NOAA HYSPLIT model (HYbrid Single-Particle Lagrangian Integrated Trajectory Model) using NCEP reanalysis meteorological repositories for 500, 1500 and $3000 \mathrm{~m}$ height levels (Draxler and Hess, 1998).

\subsection{Optical properties retrieval}

Regarding a spectral dependence of single scattering properties the $\mathrm{AE}$ was recalculated yielding the Ångstrom power law (Ångstrom, 1929):

$\sigma=B \lambda^{-\alpha}$

where $\sigma$ refers to the AOD, scattering or extinction coefficient at a given wavelength $(\lambda), B$ regards aerosol loading coefficient, and $\alpha$ represents the $\mathrm{AE}$, which was obtained from nephelometers data using 3 wavelengths (see Table 1). However, in respect to AOD obtained from Microtops II the AE exponent was estimated for 440 and $870 \mathrm{~nm}$. In addition, the single scattering albedo (SSA) was estimated yielding the following equation

$\omega=\frac{\sigma_{S C A T}}{\sigma_{S C A T}+\sigma_{A B S}}$.

where $\sigma_{\text {SCAT }}$ refers to aerosol scattering coefficient obtained from nephelometers and $\sigma_{\mathrm{ABS}}$ represents aerosol absorption coefficient measured by PAX.

Lidar data for this work has been averaged to $30 \mathrm{~m} / 10 \mathrm{~min}$ resolution. The evaluation has been done according to Ansmann et al., 1992. In this evaluation scheme first the extinction profile is calculated from the Lidar profiles at the Raman shifted colour. Next, the backscatter profile is obtained by the ratio from the elastic to inelastic Lidar profile. To obtain the aerosol extinction and backscatter, the Rayleigh contribution due to clear air is subtracted using the air density profile from the daily Vaisala RS-92 launches at 11:00 UTC at the site. For the evaluation of the IR channel at $1064 \mathrm{~nm}$ the Klett approach (Klett, 1981) has been chosen with a $\operatorname{LR}(1064 \mathrm{~nm})=30 \mathrm{sr}$.

Further, we define a depolarization ratio for aerosol (Behrendt and Nakamura, 2002) as

$\delta(z, \lambda)=\frac{\beta_{\perp}(z, \lambda)}{\beta_{\|}(z, \lambda)}$

where $\beta \perp$ is the aerosol backscatter coefficient perpendicular to the plane of polarization of the laser and $\beta_{\|}$is the aerosol backscatter coefficient in the same plane of polarization as the laser. As spherical scatters do not change the state of polarization it holds $\delta=0$ for altitudes with strictly spherical particles. Hence, $\delta$ is a quantity of the shape of the aerosol.

\section{Overview of temporal variability of aerosol optical and chemical properties during field campaign}

Fig. 2 shows temporal variability of aerosol optical properties derived from in-situ observations such as: scattering coefficient (Fig. 2a) at $550 \mathrm{~nm}$ (Ny-Ålesund) and $525 \mathrm{~nm}$ (Longyearbyen), AE for scattering coefficient (Fig. 2 b) received from TSI 3563 ( $\lambda$ : 450/ $700 \mathrm{~nm}$ ) and Aurora 4000 ( $\lambda: 450 / 635 \mathrm{~nm})$ nephelometers. However, aerosol absorption coefficient (Fig. 2c) and BC concentration $\left[\mathrm{ng} / \mathrm{m}^{3}\right]$ at $532 \mathrm{~nm}$ (Fig. 2d) were obtained from PAX instrument, as well as the SSA.

(Fig. 2e) computed by means of nephelometer and PAX data. Black lines refer to $\mathrm{Ny}$-Ålesund data, however blue dots - Longyearbyen. Regarding the latter site, due to unexpected local emission in a close neighbourhood during daytime, only data from the night hours were used for this analysis (see text following Fig. 4). Aerosol scattering coefficients from $1 \mathrm{~h}$ averaged data show a significant temporal variability within background values being below the Rayleigh scattering $\left(11.7 \mathrm{Mm}^{-1}\right.$ at $550 \mathrm{~nm}$ and for standard conditions). Mean values and standard deviations of the aerosol scattering coefficients derived from the data were equal to $8.2 \pm 4.8 \mathrm{Mm}^{-1}(550 \mathrm{~nm})$ in $\mathrm{Ny}-$ Ålesund and $7.9 \pm 3.6 \mathrm{Mm}^{-1}$ $(525 \mathrm{~nm})$ in Longyearbyen. During joint observations in Ny-Ålesund and Longyearbyen (26 Mar - 14 Apr), we found fluctuations of the scattering coefficient being in a rather good agreement with $\mathrm{AE}$. The $1 \mathrm{~h}$ mean values of $\mathrm{AE}$ are $1.38 \pm 0.33$ and $1.17 \pm 0.46$ respectively, where lowest levels were observed usually during enhancement of the scattering coefficient. The mean value and standard deviation of the absorption coefficient during a whole period in $\mathrm{Ny}-$ Ålesund and Longyearbyen were both equal to $0.8 \pm 0.4 \mathrm{Mm}^{-1}$ and $0.6 \pm 1.2 \mathrm{Mm}^{-1}$ while $\mathrm{BC}$ concentration $103 \pm 51 \mathrm{ng} / \mathrm{m}^{3}$ and $83 \pm 154 \mathrm{ng} / \mathrm{m}^{3}$ respectively. Despite the fact of $1 \mathrm{~h}$ averaging, high standard deviations of both: absorption coefficient and $\mathrm{BC}$ concentration are expected to be influenced by a significant fluctuation of PAX instruments. Thus, indicating an appreciable noise ratio. It might be concluded, that although the photoacoustic method is more appropriate to measure aerosol absorption than filter technique, PAX signal to noise ratio is low for very clean conditions occurring in the Arctic environment. The mean value of SSA retrieved from PAX and nephelometers in $\mathrm{Ny}$-Ålesund and Longyearbyen reaches a relatively low level of $0.89 \pm 0.08$ and $0.88 \pm 0.12$ respectively. The mean effective radius and standard deviation for the campaign reached value of $0.13 \pm 0.02 \mu \mathrm{m}$ for conditions in Ny-Ålesund indicating an appreciable concentration of fine particles. Its variability stays in a rather good and positive agreement with scattering coefficient. The opposite trend can be found for ratio of fine to coarse particle number concentration. A mean value for this variable is equal to $419 \pm 216$.

Taking into account that aerosol single scattering properties at the surface are mainly controlled by aerosol chemical composition, in turn controlled by air mass advections and local weather conditions we present Fig. 3 showing the diurnal mean air temperature (Fig. 3a), average and maximum wind speed (Fig. 3b), wind direction (Fig. 3c) as well as daily precipitation (Fig. 3d) in Ny-Ålesund. During the campaign a mean value of air temperature reached level of $-10.1^{\circ} \mathrm{C}$ being slightly colder in comparison to long term mean for this period (1994-2011) equal to -8.7 (Maturilli et al., 2013). The total amount of precipitation reaching $47 \mathrm{~mm}$ was slightly higher regarding long-term climatological sum of $36 \mathrm{~mm} / \mathrm{year}$ in spring (GSOD). Hence, weather in 2014 spring season was slightly colder and moister. Furthermore, increases of air temperature were usually highly connected with enhancement of both wind speed and precipitation. The averages of wind speed are comparable both reaching almost $4 \mathrm{~m} / \mathrm{s}$ (Maturilli et al., 2013).

Additionally, we found a positive correlation $(r=0.36 \pm 0.06)$ between scattering and wind speed and negligible correlation regarding absorption coefficient $(r=0.1 \pm 0.07)$. Regarding the $\mathrm{AE}$ and wind speed the correlation coefficient is negative $(r=-0.45 \pm 0.05)$. This is consistent with positive correlation of wind speed and effective radius $(r=0.43 \pm 0.06)$ and negative one with ratio of fine to coarse particle number concentration $(\mathrm{r}=-0.34 \pm 0.06)$.

Table 2 presents the frequency of wind directions and corresponding mean values of scattering coefficient, BC concentration and $\mathrm{AE}$ for all wind speeds and for weak wind conditions (less than $3 \mathrm{~m} / \mathrm{s}$ ). As it can be seen, the wind direction on the ground level is due to the orientation of the surrounding mountains mostly limited to the NW and SE directions (frequency: $21 \%, 40 \%$ respectively). 


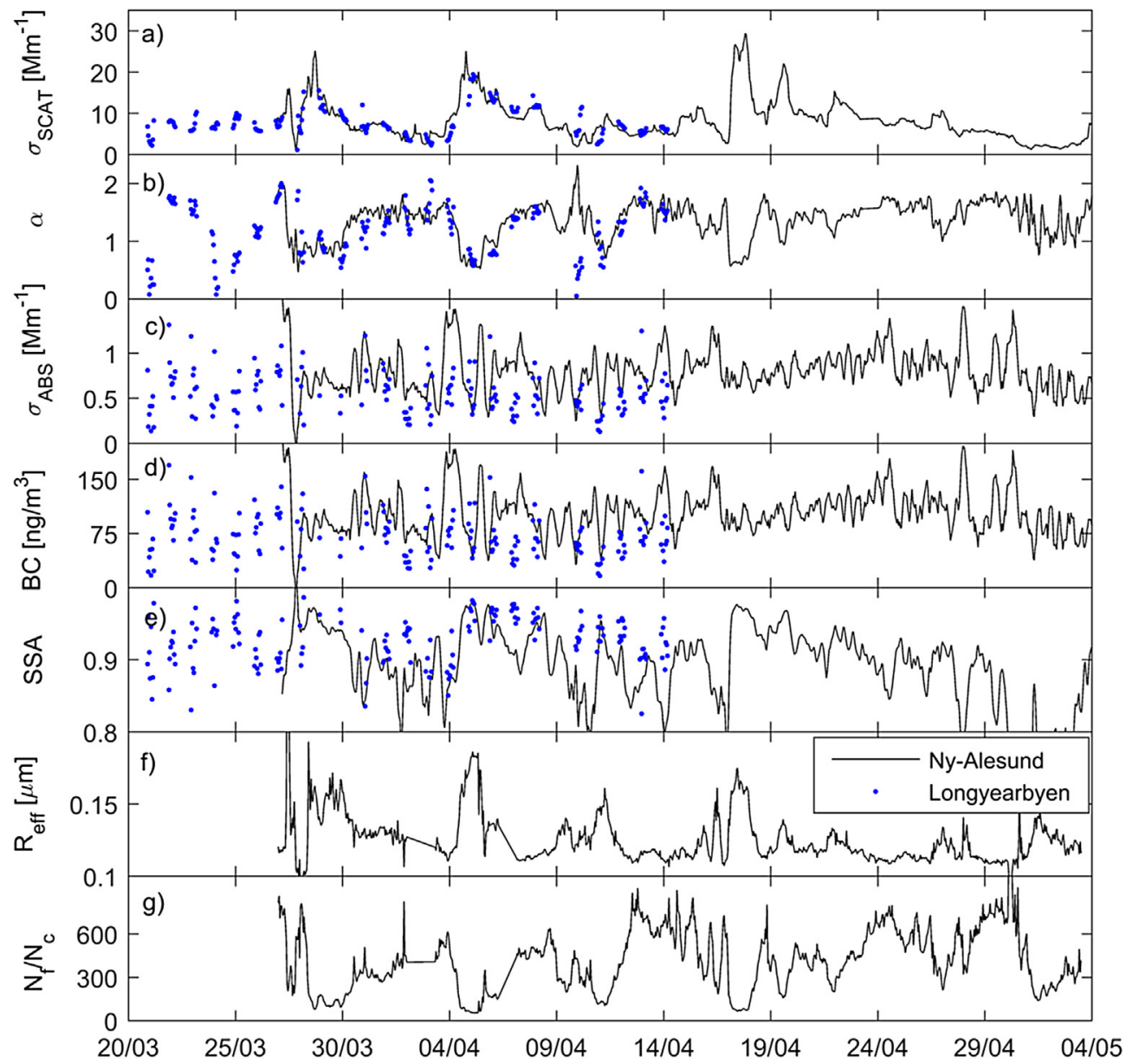

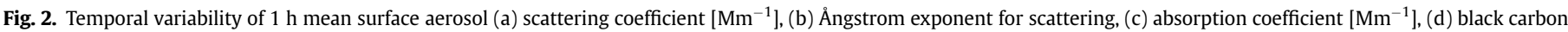

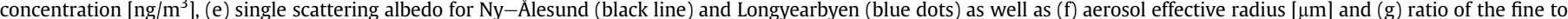

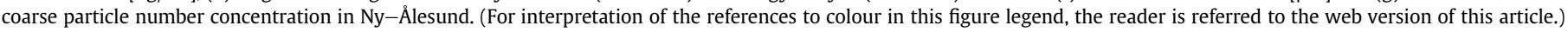

Given the cases with mass advection from N, NE, E, and SE direction, increased level of BC concentration for all wind speeds (102, 203, 135 and $112 \mathrm{ng} / \mathrm{m}^{3}$ ) might be seen. However, comparing them with cases of weak wind conditions $\left(145,203,117\right.$ and $110 \mathrm{ng} / \mathrm{m}^{3}$ accordingly), only $\mathrm{N}$ encounters higher value. As there are no pollution sources north from Ny-Ålesund, it is possible that the air mass pathway is changed due to local orography. On the other hand, there is strong evidence, that during advection from NW and $\mathrm{N}$ directions for higher wind speeds, a local production of sea-salt from the open sea is initiated. This conclusion comes from the fact that the highest values of scattering coefficient (12.6 and $12.4 \mathrm{Mm}^{-1}$ respectively) are observed for the cases and simultaneously $\mathrm{AE}$ exponent indicates a presence of larger particles in the air (values: 1.1 and 1.0). This situation disappears together with a wind speed decrease. Also, mean sea-salt concentration for NW is significantly higher $1.59 \mu \mathrm{g} / \mathrm{m}^{3}$ in comparison to SE direction $\left(0.45 \mu \mathrm{g} / \mathrm{m}^{3}\right)$ which represents advection from the land.

Taking into account the spatial variability of aerosol optical properties, Longyearbyen seems to exhibit higher levels of scattering and absorption coefficients comparing to Ny-Ålesund. Fig. 4 shows averaged diurnal variability of the scattering coefficient, AE, as well as absorption coefficient for Longyearbyen (open squares) and $\mathrm{Ny}-$ Ålesund (solid circles). Regarding the extensive parameters, a significant temporal variability was observed in Longyearbyen, where the noontime maximum of the aerosol scattering coefficient reaches level about 3 times higher than night's values.
Similar fluctuations are observed for absorption coefficient, where the maximum close to 11:00 UTC is measured. Furthermore, AE varies appreciably at the diurnal cycle with two maximum periods: around 11:00 UTC and in the evening hours (19:00-24:00 UTC). The discrepancies between Longyearbyen and $\mathrm{Ny}$-Ålesund data could be related to the daytime activity of local anthropogenic emission due to combustion processes. In addition, we found that scattering coefficient is not correlated $(r=0.1)$ with AE in Longyearbyen. However, for night hours (21:00-05:00 UTC) the correlation coefficient is slightly negative $(-0.22)$. When the emissions are reduced during night hours the values come back to the same levels as in the Ny-Ålesund except for AE which seems to be always lower. Regarding Ny-Ålesund data, we didn't observe a temporal variability of scattering and absorption coefficients as well as AE. A negative value of correlation.

coefficient between scattering coefficient and $\mathrm{AE}(-0.44)$, higher than in Longyearbyen, has been found for $\mathrm{Ny}-$ Ålesund being possibly explained by enhanced concentration of coarse particles. These changes cannot be explained by the variation of wind direction, which doesn't show any significant fluctuation between day and night hours (not shown here).

The results from sun photometer observations in Ny-Ålesund, Longyearbyen and Hornsund are presented in Fig. 5 collected by means of Microtops II (dots) and sun photometer SP1A (blue line). The mean value of AOD at $500 \mathrm{~nm}$ for Hornsund, Longyearbyen and Ny-Ålesund reaches $0.09 \pm 0.03,0.07 \pm 0.02$ and $0.06 \pm 0.02$ 


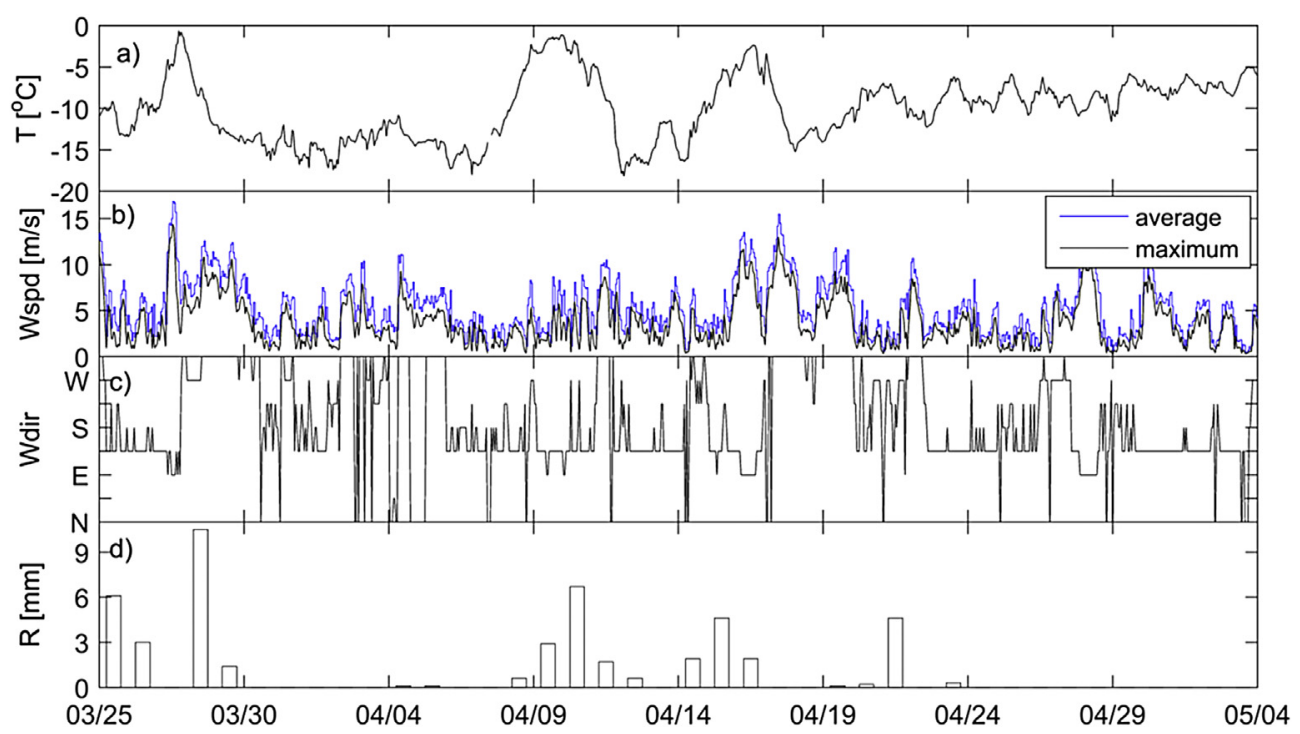

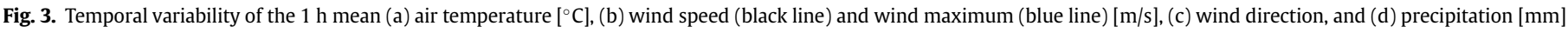

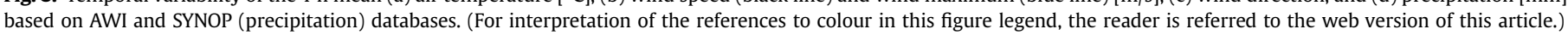

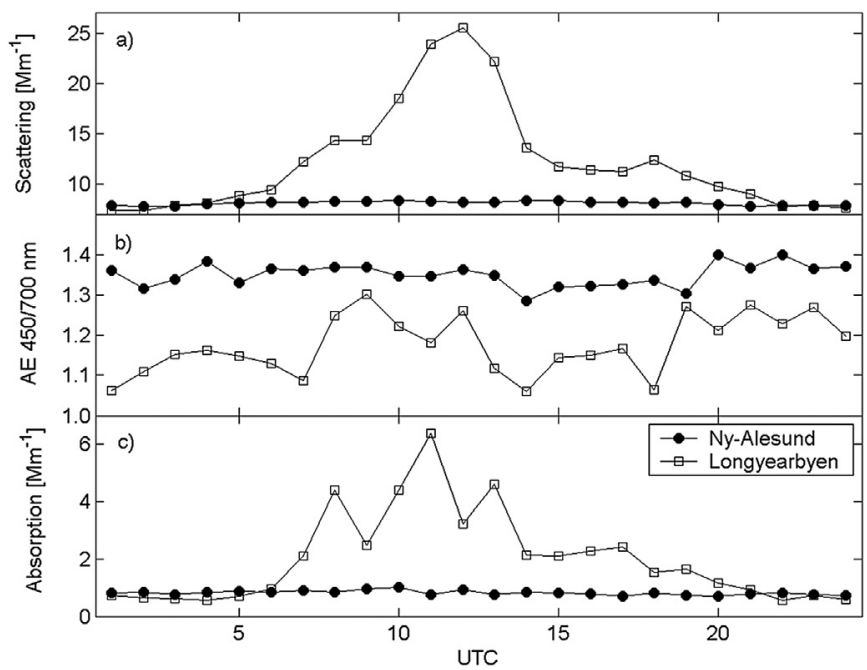

Fig. 4. Averaged diurnal cycles of (a) aerosol scattering coefficient at $550 \mathrm{~nm}$, (b) AE $(450 / 700 \mathrm{~nm})$, and (c) absorption coefficient at $532 \mathrm{~nm}$ in Ny-Ålesund (solid circles) and Longyearbyen (open squares) between 26th Mar and 14th Apr 2014.

respectively. Although Longyearbyen is more polluted town, AE seems to be lower in comparison to Ny-Ålesund measurements both reaching $1.20 \pm 0.21$ and $1.73 \pm 0.08$ respectively. Furthermore, it is much more similar to Hornsund average (1.29 \pm 0.19$)$. According to AERONET database a typical mean value of AOD (2005-2015) in Hornsund for Apr is equal to $0.11 \pm 0.05$, however $\mathrm{AE}$ is equal to $1.31 \pm 0.34$. Taking into account spring 2014 , an appreciable reduction in AOD and AE might be observed indicating more pristine conditions for iAREA2014 campaign.

Fig. 6 represents the aerosol $\mathrm{PM}_{10}$ mass concentration (6a), obtained from ion chromatography measured in Gruvebadet (Ny-Ålesund) and the relative mass contributions of the reconstructed aerosol constituents (1-5 equations), such as: sea-salt, mineral dust, secondary inorganic aerosols, without nss-sulphate, which was calculated separately and BC concentration obtained from PAX measurements (6b). These data might provide some additional information about the origin of the Arctic aerosols, however these measurements cover only the period between 31st Mar and 18th Apr of the campaign. According to Fig. 6a the mean value of $\mathrm{PM}_{10}$ concentration for the iAREA2014 campaign was $3.42 \mu \mathrm{g} / \mathrm{m}^{3}$. The contribution of components measured by ion chromatography stands for, on average, about $60 \%$ of $\mathrm{PM}_{10}$. The highest concentration of ions is observed for $\mathrm{SO}_{4}^{2-}\left(0.67 \mu \mathrm{g} / \mathrm{m}^{3}\right), \mathrm{Cl}^{-}$ $\left(0.44 \mu \mathrm{g} / \mathrm{m}^{3}\right)$ and $\mathrm{Na}^{+}\left(0.31 \mu \mathrm{g} / \mathrm{m}^{3}\right)$. During the campaign, the most important contribution to the total aerosol mass had sea-salt (about 25\%), however, for some days it reached up to 56\% (Fig. 6b). Also, nss-sulphate was of a great importance, with $19 \%$ of

Table 2

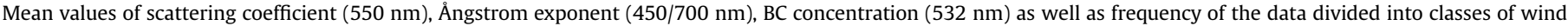
direction and wind speed (all cases and less than $<3 \mathrm{~m} / \mathrm{s}$ ).

\begin{tabular}{|c|c|c|c|c|c|c|c|c|}
\hline \multirow[t]{2}{*}{ Wind direction } & \multicolumn{2}{|c|}{ Frequency [\%] } & \multicolumn{2}{|c|}{$\begin{array}{l}\text { Scattering coefficient } \\
{\left[\mathrm{Mm}^{-1}\right]}\end{array}$} & \multicolumn{2}{|c|}{$\begin{array}{l}\mathrm{BC} \text { concentration }[\mathrm{ng} / \\
\left.\mathrm{m}^{3}\right]\end{array}$} & \multicolumn{2}{|c|}{ Ångstrom exponent } \\
\hline & All & $<3 \mathrm{~m} / \mathrm{s}$ & All & $<3 \mathrm{~m} / \mathrm{s}$ & All & $<3 \mathrm{~m} / \mathrm{s}$ & All & $<3 \mathrm{~m} / \mathrm{s}$ \\
\hline $\mathrm{N}$ & 3.3 & 1.0 & 12.4 & 7.5 & 102 & 145 & 1.00 & 1.46 \\
\hline $\mathrm{NE}$ & 0.22 & 0.22 & 9.8 & 9.8 & 203 & 203 & 1.38 & 1.38 \\
\hline $\mathrm{E}$ & 4.4 & 0.5 & 6.9 & 7.5 & 135 & 117 & 1.37 & 1.25 \\
\hline SE & 42.0 & 23.4 & 6.2 & 6.6 & 112 & 110 & 1.49 & 1.52 \\
\hline S & 8.1 & 7.7 & 7.2 & 7.0 & 109 & 110 & 1.49 & 1.49 \\
\hline SW & 8.6 & 8.2 & 7.0 & 6.9 & 97 & 97 & 1.52 & 1.53 \\
\hline W & 11.2 & 5.4 & 8.1 & 7.1 & 98 & 104 & 1.36 & 1.48 \\
\hline NW & 22.2 & 2.1 & 12.6 & 8.9 & 95 & 87 & 1.10 & 1.41 \\
\hline
\end{tabular}


component budget. Chemical measurements consider mineral dust mass a constituent of an appreciable concentration, which contribution to a total mass varies between 2 and $15 \%$ with a mean value of $4 \%$. Chemical composition of sea-salt, sulphate and mineral dust during winter-spring time reported by Tomasi et al. (2012) equal to 43, 24 and 28\% respectively, what indicates the sea-salt and sulphate mass concentration being underestimated.

After a subtraction of above aerosol constituents, still an appreciable mass of $\mathrm{PM}_{10}$ remains. One of explanations might be connected with organic carbon concentration, which plays a significant role in Arctic, as stated by a model (Fig. 7). On the other hand, Eqs. (1)-(5) may result in a high error regarding nss-sulphate and mineral dust estimation.

A comparison of the aerosol concentrations obtained from the GEM-AQ model (Fig. 7) and in-situ measurements (Fig. 6) show that the model overestimates the aerosol concentrations at the ground level in the vicinity of $\mathrm{Ny}$-Ålesund. The average concentration from GEM-AQ is equal to about $6 \mu \mathrm{g} / \mathrm{m}^{3}$ at the surface, whereas in-situ measurements indicate mean value on a level of $3.4 \mu \mathrm{g} / \mathrm{m}^{3}$. According to GEM-AQ model, Arctic air during iAREA2014 mostly consisted of aerosols such as sulphate (30\%), organic carbon (27\%) and sea salt (20\%). Mineral dust and BC were considered minor components with an average concentration of 13 and $10 \%$. Given the in-situ chemical data, one may conclude, that model appreciably overestimates the contribution of sulphates, BC and mineral dust to $\mathrm{PM}_{10}$ concentration in the ground layer. In contrary, the input of sea-salt is significantly lower. It shows the maximum of BC concentration in the surface layer of $1 \mu \mathrm{g} / \mathrm{m}^{3}$ at the beginning of campaign and about $0.5 \mu \mathrm{g} / \mathrm{m}^{3}$ at the end of the experiment. Also, model indicates an opposite trend for sulphate contribution: from $30^{\text {th }}$ Mar to 19th Apr, we observed rather decreasing trend for measured sulphate, while modeled results show a graduated increase. Regarding the vertical profiles of aerosol composition (Fig. 8) obtained from the model, one might see, that all of components concentrates in the surface layer up to 1-3 km depending on the particular aerosol type. On days with elevated sea-salt concentration its vertical profiles reach only $1 \mathrm{~km}$ indicating the transport within the lowest part of troposphere. The results come with appreciable agreement with statement that $\mathrm{BC}$ and mineral dust are mainly transported from long-range distances, as they have no significant sources around Ny-Ålesund, so they tend to accumulate in a free troposphere (Heintzenberg et al., 1981; Rozwadowska et al., 2010).

Average profiles of the extinction coefficient $\left[\mathrm{Mm}^{-1}\right]$ and the backscatter coefficient $\left[\mathrm{Mm}^{-1} \mathrm{sr}^{-1}\right]$ both at $532 \mathrm{~nm}$ derived from the KARL Lidar are depicted in Fig. 9. All cloud screened data from the whole iAREA2014 campaign have been averaged for the mean profile while the profiles of the selected individual days refer to long measurements (at least $3 \mathrm{~h}$ without clouds). It can be seen that extinction profiles roughly agrees to the GEM-AQ model (Fig. 8), which depicts higher aerosol concentrations in low altitudes. In fair agreement to the AOD in the photometers the integrated extinction in the Lidar between 1 and $10 \mathrm{~km}$ altitude is $0.07 \mathrm{from}$ which half of the aerosol was located below $3 \mathrm{~km}$ altitude. Also the average aerosol depolarization during the campaign (not shown here) is with only $1.73 \%$ in all altitudes very low, indicating that non-spherical aerosol components (mineral dust), have not been frequent. It meets the results from the surface data (Fig. 6).

Some particular days with increased aerosol load on the surface will be discussed later in Section 4.2. The only day, which overlaps with long Lidar observations, was 6 April. During that day values of extinction around $4 \mathrm{~km}$ altitude as well as depolarization of 3.5\% above $3 \mathrm{~km}$ indicate some long-range transport of dust. A more detailed analysis of Raman-Lidar derived optical properties during iAREA2014 campaign will be presented in paper 2 .

\section{Case study - aerosol advections during the campaign}

In accordance to mentioned in-situ data the campaign might be divided into three separate periods signifying alternate cycles of clear weather conditions and aerosol advection events. During the advections, enhanced extensive single scattering properties of aerosols might be seen. A detailed description of significant phenomenon based on the Ny-Ålesund observations can be found in the following chapter.

\subsection{Event between 27 and 28 Mar}

The first event period appeared between 27 and 28th Mar, where increased extensive aerosol properties were observed. Moreover, air mass transport might have originated from two different sources due to instant change of aerosol optical properties within the period. Regarding HYSPLIT back trajectories the air origin can be defined. Taking into account aerosol transport, during 27th of Mar, NCEP reanalysis shows transport from the north-western Asia via the eastern part of Arctic Ocean $(500,1500$, $3000 \mathrm{~m}$ ) (Fig. 10). For the next day, HYSPLIT indicates advection from north-eastern part of Greenland for 500 and $1500 \mathrm{~m}$, moreover, air mass at $3000 \mathrm{~m}$ possibly origins from Labrador Sea. Analysis of GEM-AQ $24 \mathrm{~h}$ forecast for the period confirms that

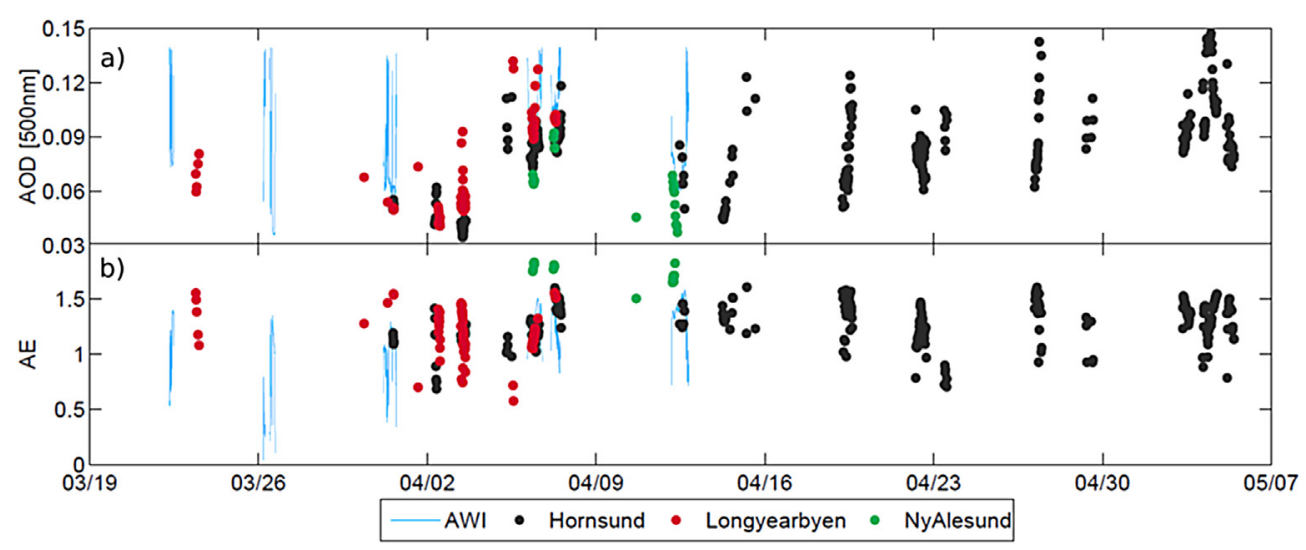

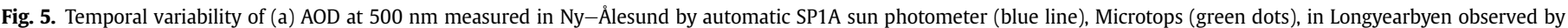

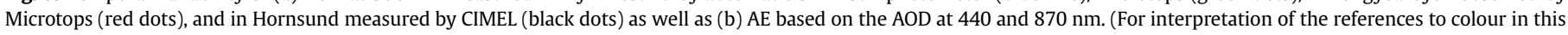
figure legend, the reader is referred to the web version of this article.) 


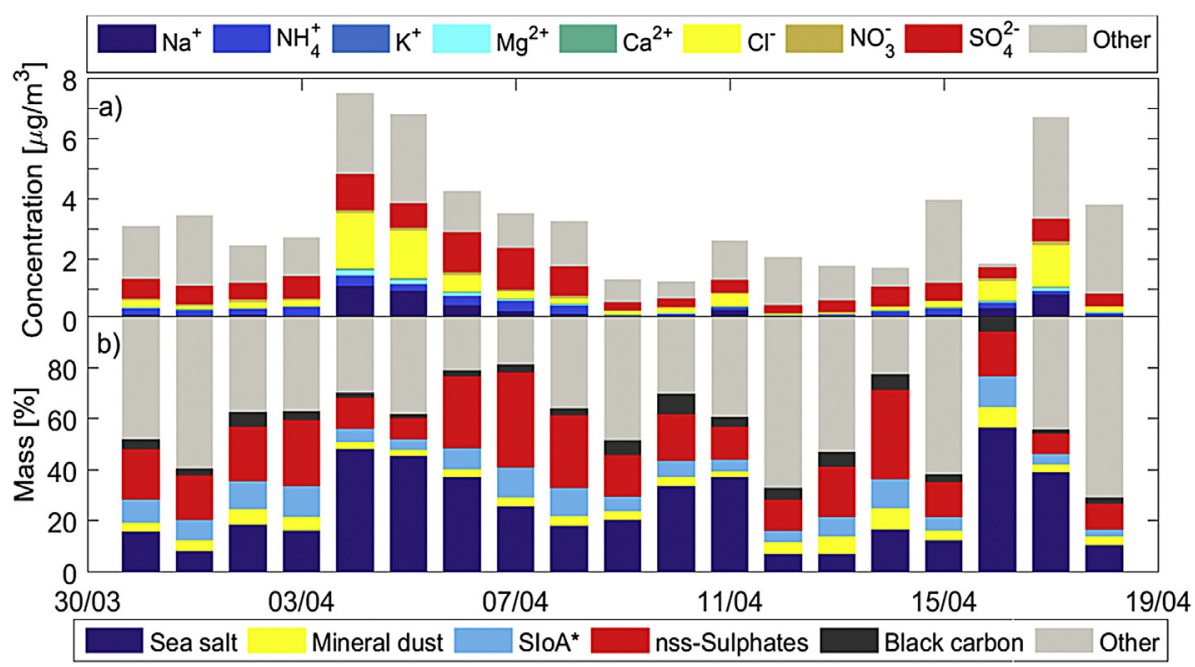

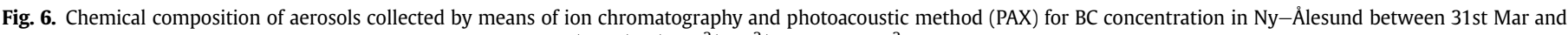

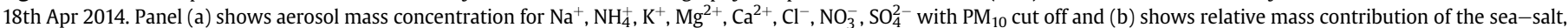
mineral dust, secondary inorganic aerosol (SIoA) (without nss-sulphate), nss-sulphate, and black carbon to a $\mathrm{PM}_{10}$ total mass.

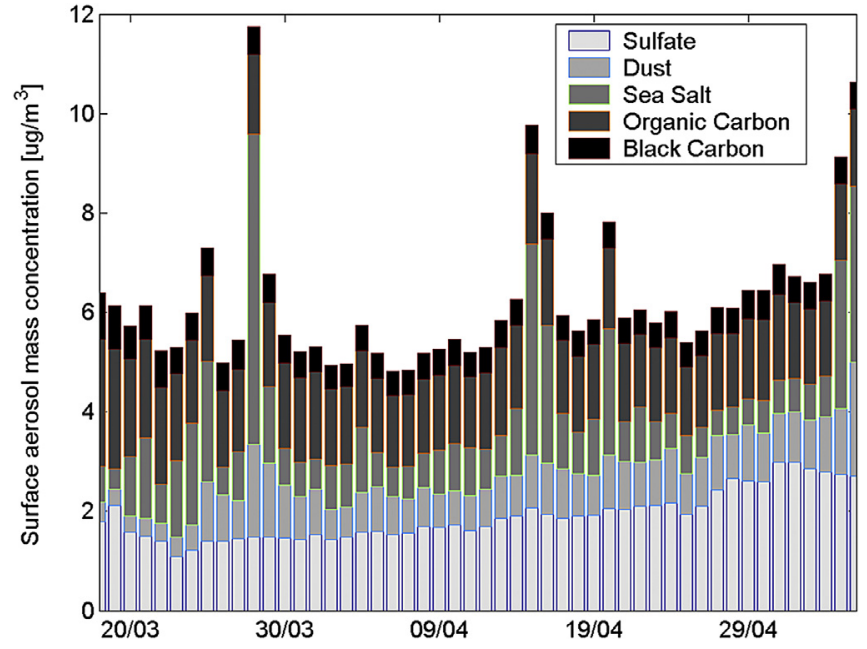

Fig. 7. Daily average of chemical aerosols composition of aerosols during the campaign obtained from the GEM-AQ model.

major contribution to the elevated aerosol levels was connected with sea-salt concentrations, where the highest modeled levels were forecasted on 28th of Mar at 10:00 UTC with the maximum up to $17 \mu \mathrm{g} / \mathrm{m}^{3}$. The increase of sea-salt aerosol was related to the inflow from northern and north-western directions (Fig. 11). During the episode the model forecasted strong winds, up to $25 \mathrm{~m} / \mathrm{s}$ at a grid point corresponding to the Ny-Ålesund location.

The first phase occurred on 27th of Mar when scattering coefficient reached a value of $16 \mathrm{Mm}^{-1}$ at $550 \mathrm{~nm}$ (Fig. 2a). However, the most significant change was emphasised in absorption coefficient to a level of $3.5 \mathrm{Mm}^{-1}$ (Fig. 2b) and BC concentration equivalent to $225 \mathrm{ng} / \mathrm{m}^{3}$. During the largest scattering coefficient increase, we further observed reduction of the AE below 1 (Fig. 2b) and significant enhancement of aerosol effective radius up to $0.3 \mu \mathrm{m}$ (Fig. 2f). Moreover, reduction of the fine to coarse particle number concentration ratio (Fig. $2 \mathrm{~g}$ ) as well as high wind speed (Fig. 3b), up to $15 \mathrm{~m} / \mathrm{s}$, might have indicated a local emission of large particles (sea-spray), which predominated in the near surface atmosphere. During the afternoon of 27th wind speed decreased significantly to $1 \mathrm{~m} / \mathrm{s}$, indicating lower advection of air mass now from SE and increasing again to $4-5 \mathrm{~m} / \mathrm{s}$ around midnight. During minimum of the wind speed, one might observe the minimum of aerosol scattering (below $2 \mathrm{Mm}^{-1}$ ), aerosol absorption (almost zero), an increase of the $\mathrm{AE}$ to 1.5 and reduction of effective radius to $0.1 \mu \mathrm{m}$. This fast change in aerosol optical and microphysical properties during 27th of Mar can be explained by the descending movement of the mesoscale low pressure system during that time. It reflects the mentioned reduction of wind speed and change of wind direction, which induced a significant decrease of aerosol scattering and further sea-salt local advection. In addition, significant (about $6 \mathrm{~mm} /$ day) snow precipitation on 27th of Mar (Fig. 3d) indicated intensive wet deposition processes, which removed the aerosol particles from the lowest part of atmosphere.

On 28th, aerosol optical characteristics changed, indicating a second phase of the event period, where scattering properties predominated. Scattering coefficient reached a local maximum of $25 \mathrm{Mm}^{-1}$ while absorption coefficient decreased to $0.8 \mathrm{Mm}^{-1}$. Moreover, the number of small particles decreased and AE dropped to a level of 1.0. During this day the wind speed was up to $12 \mathrm{~m} / \mathrm{s}$ from NW, indicating sea-salt production and transport from the open water.

For this event Lidar data were not available due to cloud cover. However, at the late evening extinction coefficient retrieved from Lidar for the lowermost layer was measured reaching $30 \mathrm{Mm}^{-1}$ $(532 \mathrm{~nm})$, which is significantly higher in comparison to in-situ measurements. The issue might be related to the hygroscopicity of the particles, which were reported by Zieger et al. (2010) to enhance scattering coefficient by a factor of 2-6 for the conditions occurring in Ny-Ålesund. Alternatively the aerosol might have arrived at distinct layers in the atmosphere, as the photometers and the Lidar derived similar values.

\subsection{4-6 April event}

During these days high concentration $\left(7.6 \mu \mathrm{g} / \mathrm{m}^{3}\right)$ of $\mathrm{PM}_{10}$ was measured indicating elevated levels of sea-salt concentrations. The most probable reason for the occurrence of the event might be found in a change in wind speed. Although its level over land of $5-7 \mathrm{~m} / \mathrm{s}$ was measured, HYSPLIT and GEM-AQ show its value to be much higher over ocean, causing local production and transport of 


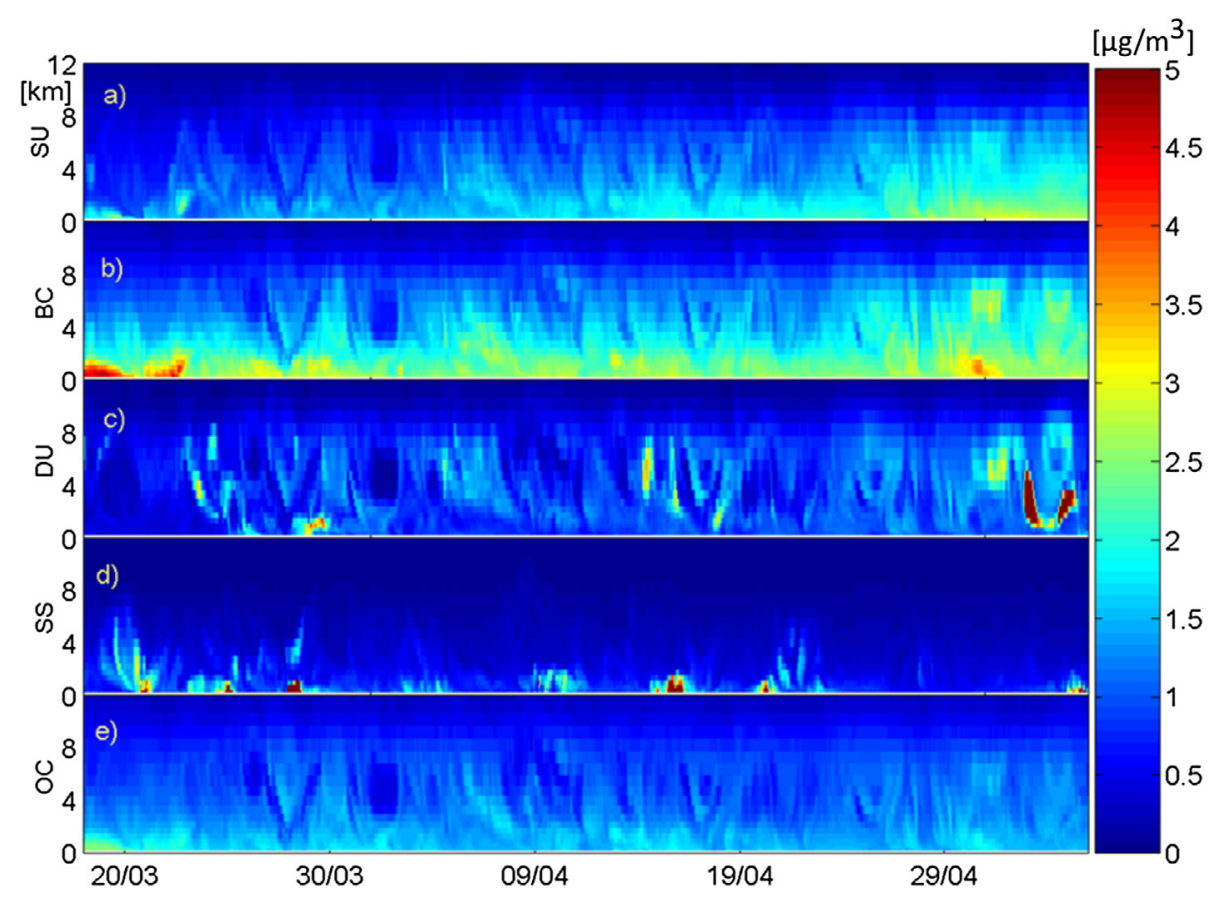

Fig. 8. Vertical profiles of aerosol chemical composition $\left[\mu \mathrm{g} / \mathrm{m}^{3}\right]$ : (a) sulphate (SU), (b) black carbon (BC), (c) dust (DU), (d) sea-salt (SS) as well as (e) organic carbon (OC) in $\mathrm{Ny}-$ Ålesund during the campaign obtained from GEM-AQ. The unit for (b) black carbon is lower with the magnitude of 5.

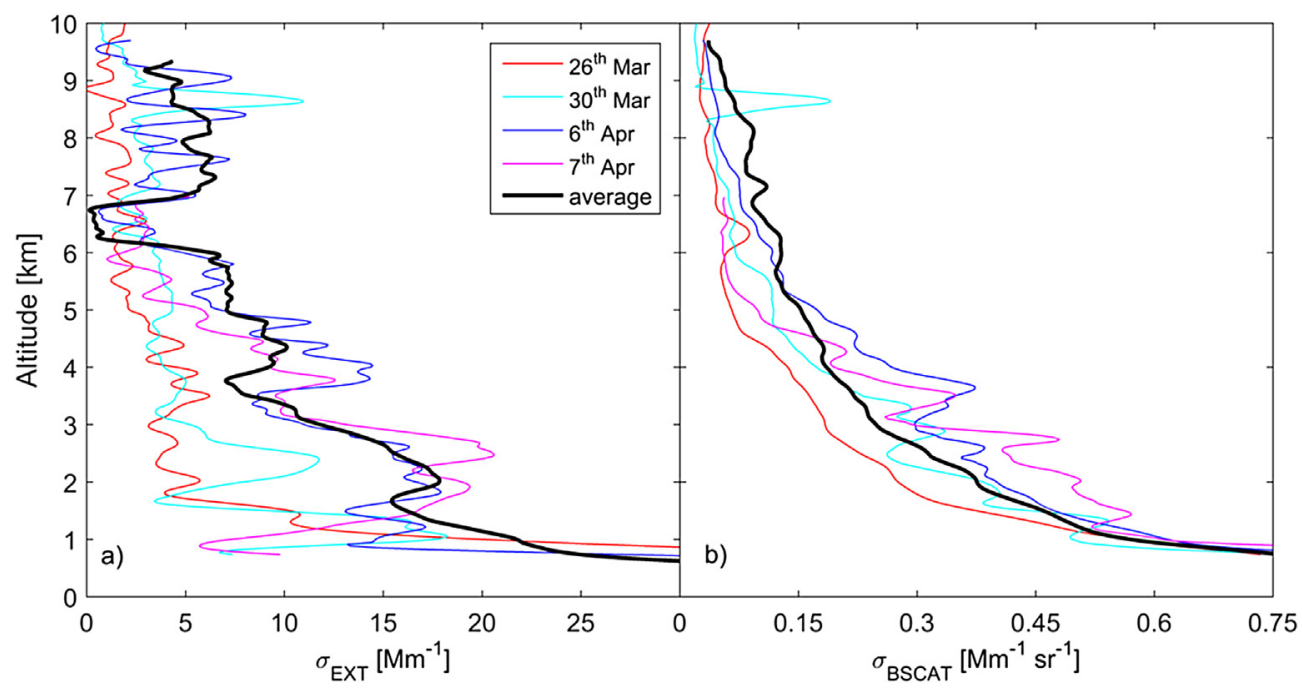

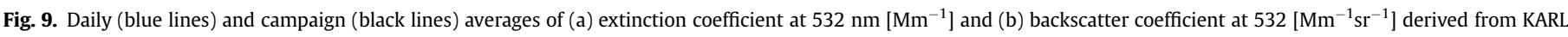
Lidar during iAREA2014 campaign. (For interpretation of the references to colour in this figure legend, the reader is referred to the web version of this article.)

sea-salt. Beginning with 04.04.2014 12:00 UTC back trajectories (Fig. 12a) from HYSPLIT, the model implies advection of all levels from the Central Siberian Plateau. Described situation changed on the next day (Fig. 12b), where air mass is brought from the region around the Franz Josef Islands (both 500 and $1500 \mathrm{~m}$ ). Hence, it continues for the next day being finally changed by mesoscale cyclonic movements.

During 4-6th Apr episode, increased concentrations of sea-salt aerosol were forecasted by the GEM-AQ model within the boundary layer, and another one, containing mineral dust in the free troposphere at $5 \mathrm{~km}$. Elevated concentrations of sea-salt were forecasted with the maximum of about $2.8 \mu \mathrm{g} / \mathrm{m}^{3}$ on 3rd of April (22:00 UTC). High concentrations of mineral dust with a maximum on 4th of April (16:00 UTC) were connected with the long-range transport from northern Russia. Increased wind speed and flow structure were governed by a deep low-pressure system over the Bear Island (Fig. 13).

From Apr 4th 11:00 UTC, the particle concentration suddenly rises due to the wind speed increase. What is more, the highest concentration of $1.2 \mu \mathrm{g} / \mathrm{m}^{3}$ is observed for aerosol size range around 0.7-2.0 $\mu \mathrm{m}$ (Fig. 14). Also, scattering coefficient increased significantly to a maximum level of $22 \mathrm{Mm}^{-1}$ at 18:00 UTC on 4th of Apr. After that, the value systematically decreased to $10 \mathrm{Mm}^{-1}$ at the end of 6th Apr (Fig. 2a). Absorption coefficient varied between zero and $2 \mathrm{Mm}^{-1}$ indicating significant noise of the PAX instrument. On the 4th of Apr the AE dropped to relatively low values (0.5) while 


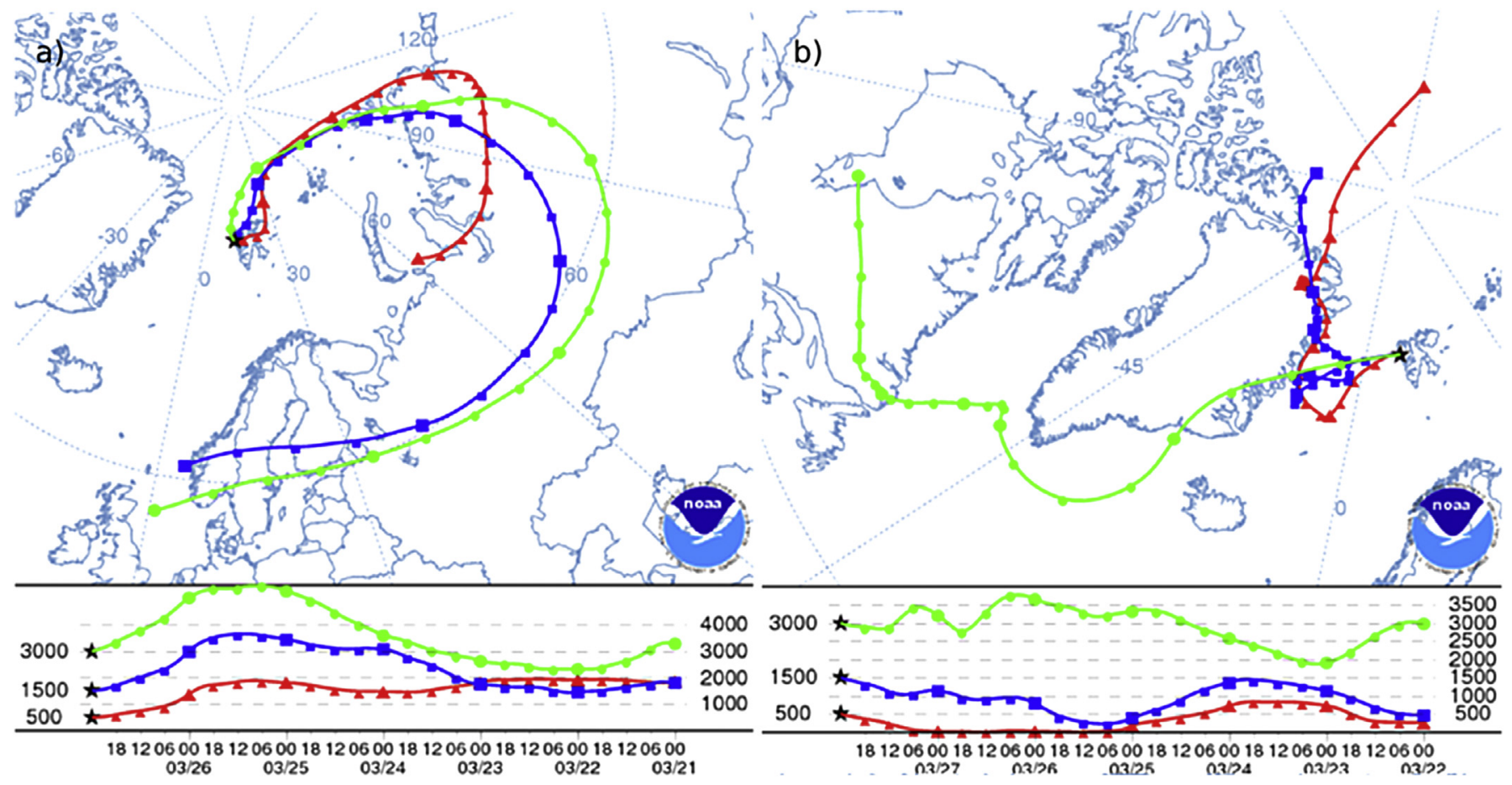

Fig. 10. $144 \mathrm{~h}$ back trajectories obtained from NOAA HYSPLIT model generated by means of NCEP reanalysis for (a) 27.03.2014 00:00 UTC and (b) 28.03.2014 00:00 UTC.

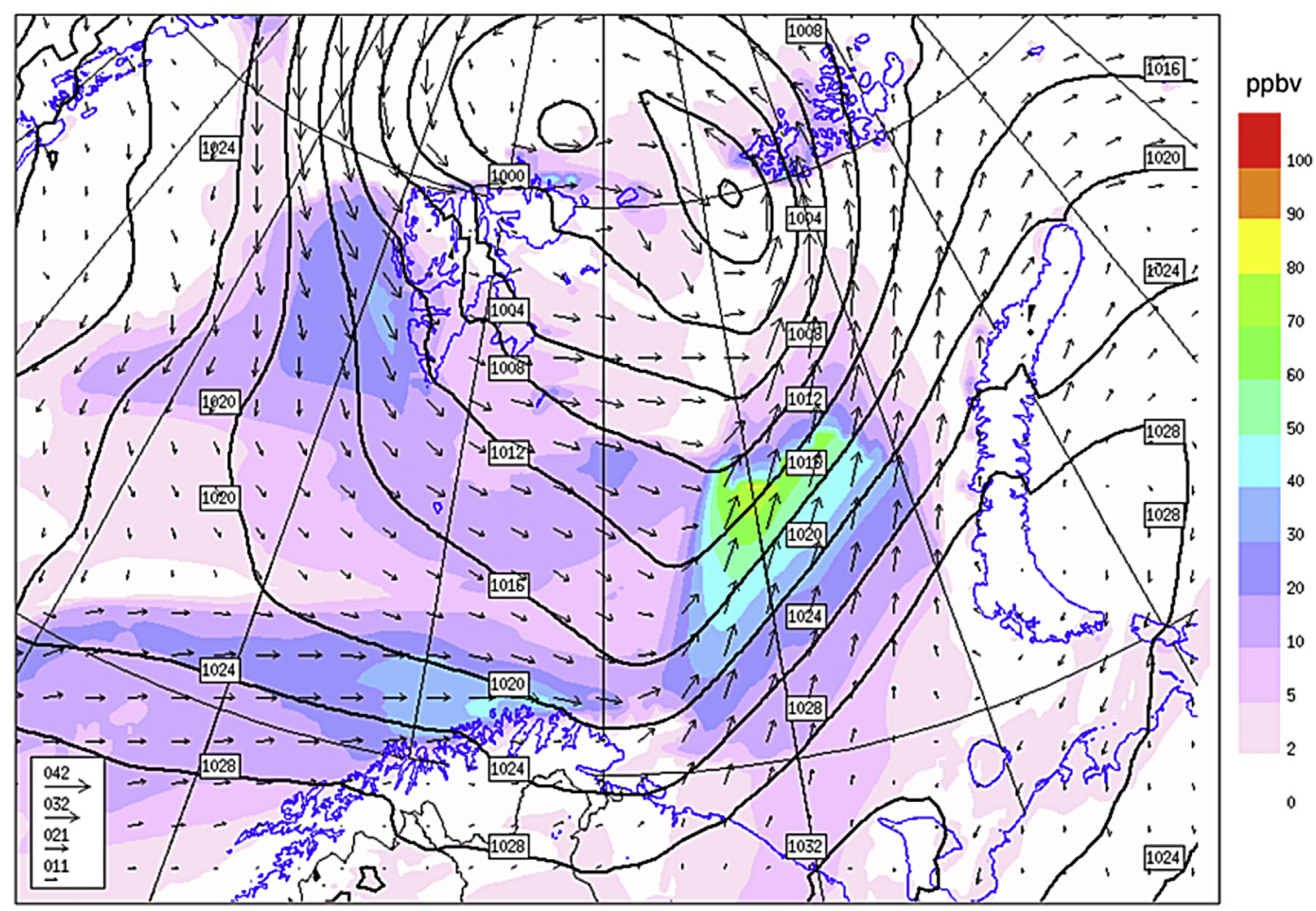

Fig. 11. Sea-salt mixing ratio [ppbv], mean sea level pressure [hPa] and wind speed [knots] on 28 of Mar 10:00 UTC from GEM-AQ.

effective radius increased up to $0.2 \mu \mathrm{m}$. Aerosol size distribution measurements by LAS show a large reduction of the fine to coarse particle number concentration ratio. According to $24 \mathrm{~h} \mathrm{PM}_{10}$ and 4-stage sampling, Ny-Ålesund is dominated by the air mass, which most likely consists of sea-salt particles due to high concentration of $\mathrm{Na}^{+}$particles in coarse mode (Table 3). Overall, we might conclude that an advection from the Asian sector was observed as confirmed by nss-sulphate marker. During the first 
day high wind speed initiated additional enrichment of sea-salt in the air mass. After passing of the low pressure system (morning Apr 5th), the AE starts to increase, followed by rising of the particle concentration in the sub-micrometric range. At the end of the event period, the surface optical properties return to the mean level. Hence, chemical analysis for days (5, 6, 7, 8 Apr) (Fig. 6a) clearly shows a decreasing trend of $\mathrm{Na}^{+}$and an increasing trend for sulphate (up to $1.4 \mu \mathrm{g} / \mathrm{m}^{3}$ on 7th Apr) (Fig. 6a) indicating further transport of anthropogenic sulphate in the sub-micrometric mode. Since wind speed decreased a sea-salt production disappeared leaving anthropogenic load in the air mass. AOD measurements obtained from CIMEL and Microtops II sun photometer $(500 \mathrm{~nm})$, indicated some spatial variability between 4th and 6th Apr (Fig. 5). The highest value was observed in Longyearbyen (0.09-0.13) through Hornsund data $(0.07-0.11)$, finishing with $\mathrm{Ny}-$ Ålesund (0.06-0.1). Most of presented values are still rather below the long-term mean for the Apr (0.1-0.11) (Hornsund AERONET database).

Due to clouds, only short Lidar observations were successful during noon on Apr 3rd and 5th, and a long observation on Apr 6th (Fig. 9), which shows a decreasing extinction coefficient over time. However, we did not find a close relation between the extinction or absorption values on the ground and the backscatter or extinction from the Lidar in the column. Instead, the Lidar data indicates a general clearing of the low troposphere: the mean extinction coefficient averaged between $850 \mathrm{~m}$ and $1100 \mathrm{~m}$ altitude of $13.0 \mathrm{Mm}^{-1}$ on Apr 6th.

\subsection{7-19 April event}

Regarding HYSPLIT back trajectories (Fig. 15) on 17th Apr NCEP implies the central Arctic Ocean $(500 \mathrm{~m})$ as well as western part of the Barents Sea, including northern Scandinavian Peninsula $(1500 \mathrm{~m})$, to be the areas of air mass origin. On 18th a change in advection might be observed, where direction via north coast of Greenland and the North Pole to the Asian coastal region of Siberia is predominant. Hence, HYSPLIT results for this period indicate transport of the sea air mass from around the Arctic Ocean. According to GEM-AQ results (Fig. 16), during the analysed episode sea-salt particles dominated in the total aerosol load with the highest concentrations calculated within the boundary layer (up to $8.9 \mu \mathrm{g} / \mathrm{m}^{3}$ ) on 16th of Apr at 02:00 UTC. Further elevated sea-salt flux was obtained and strongly connected with modeled high wind speed of $22 \mathrm{~m} / \mathrm{s}$ in a low pressure system moving over Svalbard (Fig. 16). The movement of the low caused the inflow of sea-salt from the northern direction on Apr 17th, which agrees with HYSPLIT back trajectories.

Between 17th and 19th of Apr, scattering coefficient increased significantly on the first and last day indicating some aerosol advection (Fig. 2a). The event began on 17th Apr at 03:00 UTC by enhancing the concentrations of particles population in the range of $0.5-1.5 \mu \mathrm{m}$ (Fig. 17). This situation lasted till the next morning, where the decrease of dominating particles between 3:00 and 8:00 UTC is observed. On 17th the scattering coefficient reached $30 \mathrm{Mm}^{-1}$ while on 19 th $22 \mathrm{Mm}^{-1}$. Similarly to the previous events during increase of scattering coefficient, we observed reduction of $\mathrm{AE}$ to about 0.5 on 17th and to 1.0 on 19th of Apr (Fig. 2b). Moreover, the increase of the effective radius and reduction of fine to coarse particle number concentration additionally might be examined. Given meteorological diagrams (Fig. 3), a noticeable change of the wind direction from SE-E to NW (Fig. 3c) might be seen as well as an increase of wind speed up to $9-10 \mathrm{~m} / \mathrm{s}$ on 17 th of Apr and $6-8 \mathrm{~m} / \mathrm{s}$ on 19th of Apr (Fig. 3b) which further induced production of sea-spray being subsequently transported over Ny-Ålesund. Chemical $\mathrm{PM}_{10}$ filter analysis on 17th of Apr shows a dominant contribution of sea-salt, marked by a very high $\mathrm{Na}^{+}$concentration of $0.83 \mu \mathrm{g} / \mathrm{m}^{3}$ and a significant sulphate concentration (about $0.74 \mu \mathrm{g} / \mathrm{m}^{3}$ ) (Fig. 6a). Unlike the 4-6 Apr event, the 4-stage

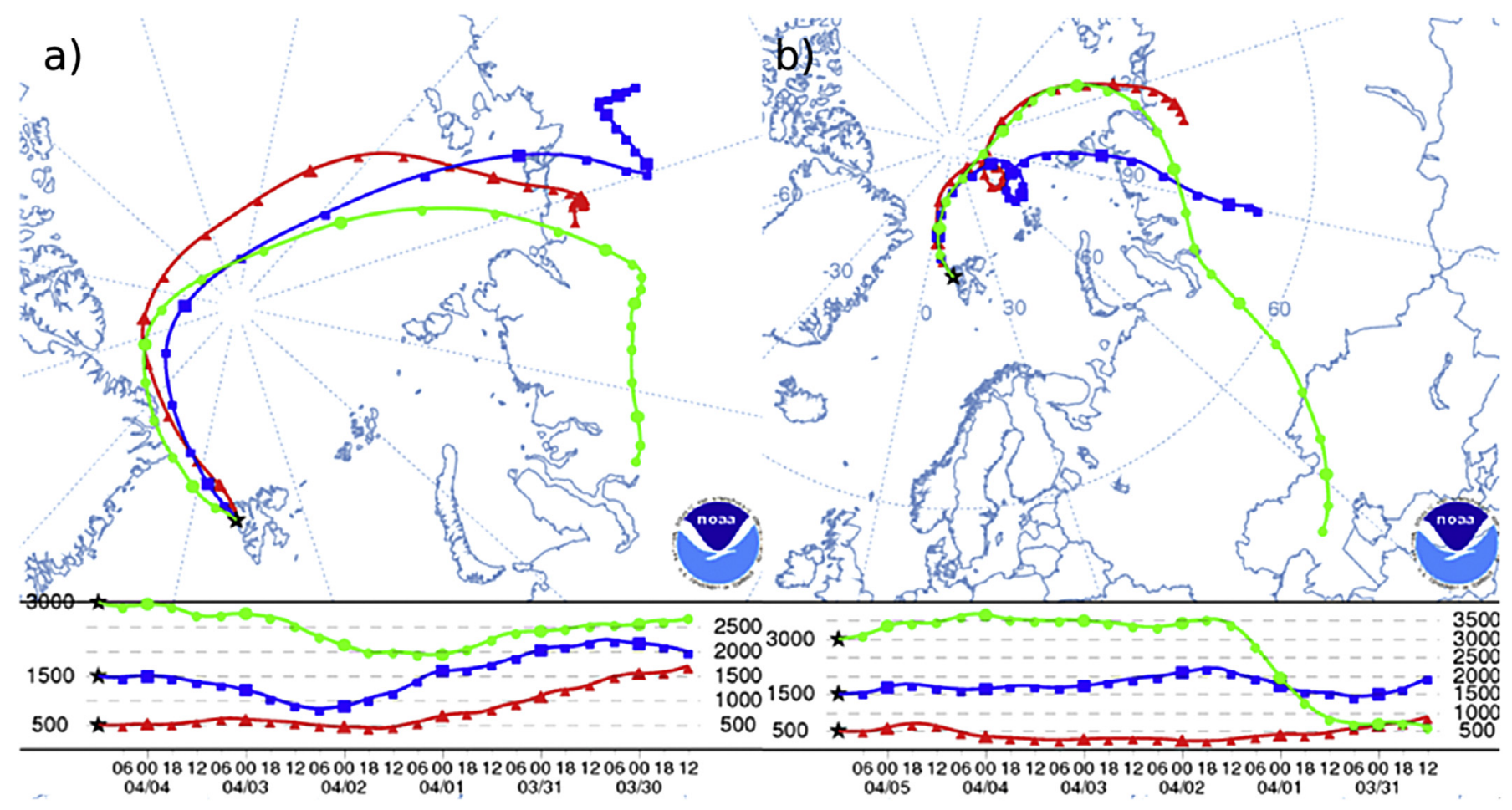

Fig. 12. $144 \mathrm{~h}$ back trajectories obtained from NOAA HYSPLIT model generated by means of NCEP reanalysis for (a) 04.04.2014 12:00 UTC and (b) 05.04.2014 12:00 UTC. 


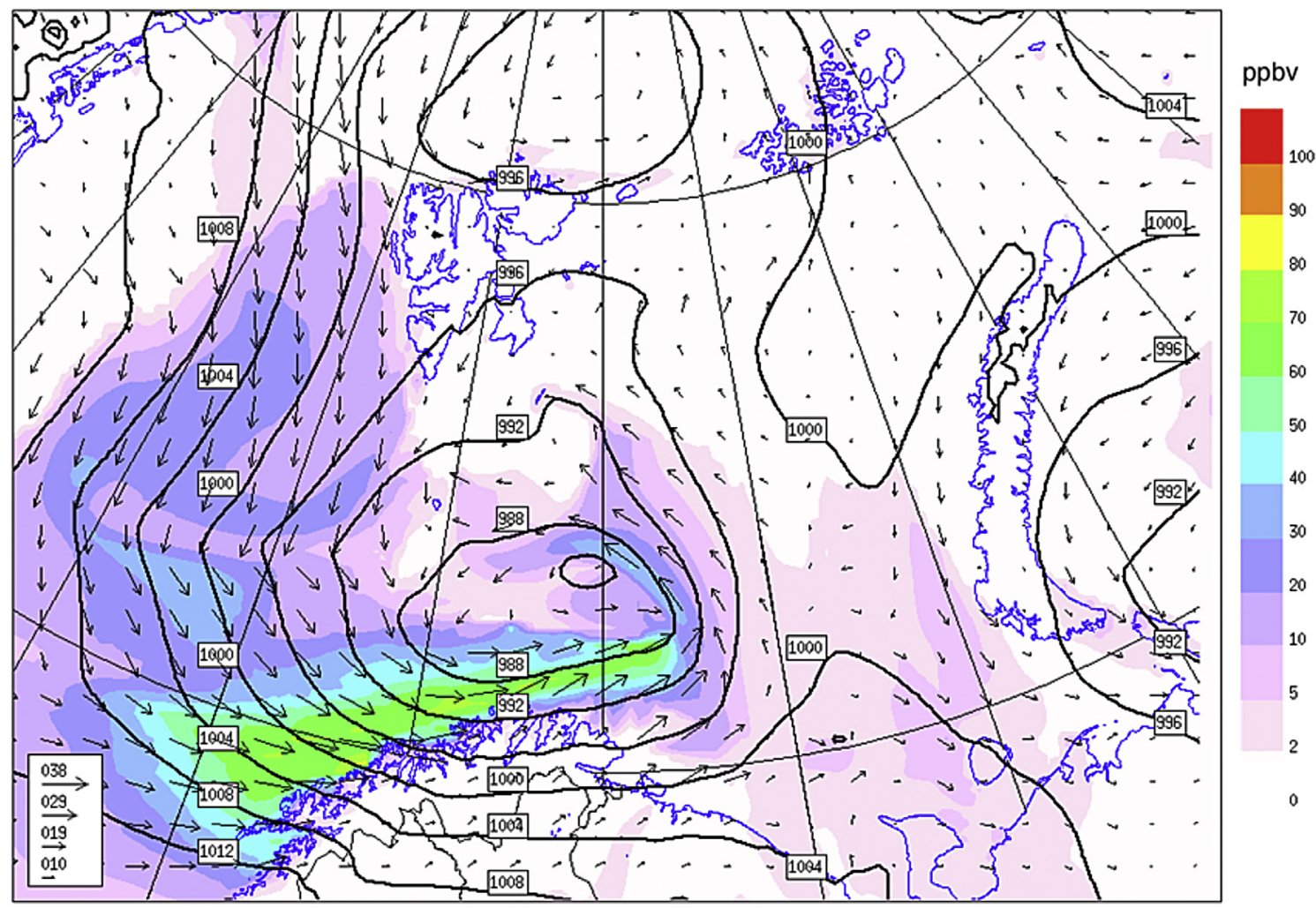

Fig. 13. Sea-salt mixing ratio [ppbv], mean sea level pressure [hPa] and wind speed [knots] on 4th of April - 14:00 UTC.

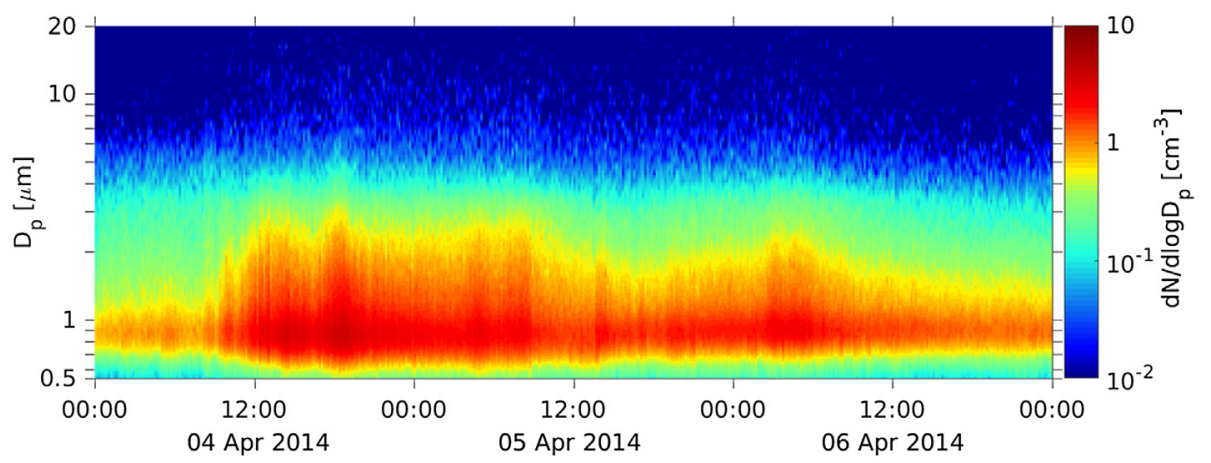

Fig. 14. Variability of aerosol number size distribution in Ny-Ålesund during 4-6th Apr 2014.

Table 3

Concentration of $\mathrm{Na}^{+}$as well as $\mathrm{nsSSO}_{4}^{2-}$ particles in Ny-Ålesund during 4-6th Apr 2014.

\begin{tabular}{|c|c|c|c|c|}
\hline & $<1.0 \mu \mathrm{m}\left[\mathrm{ng} / \mathrm{m}^{3}\right]$ & $1.0-2.5 \mu \mathrm{m}\left[\mathrm{ng} / \mathrm{m}^{3}\right]$ & $2.5-10 \mu \mathrm{m}\left[\mathrm{ng} / \mathrm{m}^{3}\right]$ & $>10 \mu \mathrm{m}\left[\mathrm{ng} / \mathrm{m}^{3}\right]$ \\
\hline $\mathrm{Na}^{+}$ & 151.2 & 223.9 & 123.0 & 18.9 \\
\hline $\mathrm{nssSO}_{4}^{2-}$ & 402.4 & 61.8 & 1.6 & 7.8 \\
\hline
\end{tabular}

impactor data (Table 4) indicates sea-spray to be distributed in two size classes: $1-2.5 \mu \mathrm{m}$ and less than $1.0 \mu \mathrm{m}$, probably caused by a long range transport (or aging of sea-spray). The presence of a significant sulphate contribution supports more, however, the long range transport hypothesis. As a consequence, the dominance of relatively large particles (around $1.0 \mu \mathrm{m} ; 0.5-1.5 \mu \mathrm{m}$ range) lowers the $\mathrm{AE}$ value (around 0.5 on 17th Apr) and decreases the fine to coarse particle concentration ratio. On the 18th wind speed reduced to $3-4 \mathrm{~m} / \mathrm{s}$ and aerosol scattering coefficient to about $10 \mathrm{Mm}^{-1}$. Chemical data indicates, that $\mathrm{Na}^{+}$and sulphate concentrations are lower (Fig. 6a), causing a decrease in the scattering coefficient (Fig. 2a). However, $\mathrm{Na}^{+}$drops to very low values $\left(0.15 \mu \mathrm{g} / \mathrm{m}^{3}\right.$, about 6 times lower than the day before). Sulphate, on the other hand, remains relatively high $\left(0.4 \mu \mathrm{g} / \mathrm{m}^{3}, 1.5\right.$ times lower than the day before), hence, it dominated in the aerosol population (Fig. 6a). Since sulphate was distributed in the sub-micrometric mode, the $\mathrm{AE}$ values and ratio of fine to coarse mode particle concentration increased (Fig. 2b, g). During the event the absorption coefficient didn't show any significant change, as fluctuation around $0.5-1.0 \mathrm{Mm}^{-1}$ was noisy. 


\section{Conclusions}

In this paper we discussed aerosol optical, microphysical and chemical properties observed during iAREA2014 campaign in Ny-Ålesund and Longyearbyen. Temporal variability of the single scattering properties at both sites indicates a few event days with a significant increase of extensive optical properties. Based on the chemical measurements of aerosol composition, numerical simulation by the GEM-AQ model as well as the weather condition, we found that almost all aerosol scattering events in $\mathrm{Ny}$-Ålesund during 2014 spring are due to sea-salt emission. Furthermore, we additionally observed, that sulphate particles transported from anthropogenic sources had a significant contribution to the aerosol mass concentration. The correlation coefficient for daily mean sea-salt mass concentration and wind speed is 0.53 , with a confidence interval \pm 0.1 at $\alpha=0.05$. Probably the correlation between sea-salt mass and wind speed is higher in case of larger time resolution. Results presented in the case study section show that wind speed may change significantly during the day as well as the single scattering properties. Therefore the $24 \mathrm{~h}$ time based, in case of chemical composition, measurements cannot describe the realistic sea-salt temporal variability. We found the negative correlation between the scattering coefficient and $\mathrm{AE}(\mathrm{r}=-0.44 \pm 0.05)$, which indicates that large particles are responsible for the events. This is typical for regions with very small impact of the fine anthropogenic particles. Results of chemical measurements indicate that sea-salt mass concentration contribution to the total mass oscillates between 7 and 57\%. Significant contribution $(8-37 \%)$ is due to sulphate aerosol. Also, the mineral dust has a noticeable impact (2-9\%) in the total $\mathrm{PM}_{10}$ mass concentration at the surface, however, its calculations might encounter a significant estimation error. On the other hand, smaller contribution of this component in comparison to Tomasi et al. (2012) might be related to its height of advection. Thus, GEM-AQ simulations show the dust is mostly transported in the upper troposphere, albeit the model seems to overestimate aerosol load in general.

During the campaign, the variability of the absorption coefficient in Ny-Ålesund is much less than the variability of the scattering coefficient. However, even for $1 \mathrm{~h}$ data averaging the absorption coefficient and BC concentration from PAX instruments show large fluctuations. Based on the measurement made in Central Europe, we conclude the PAX shows much better signal-to-noise ratio for more polluted conditions. Temporal variability of BC taken from GEM-AQ model is small and consistent with in-situ observation. Overall, our sea-salt fraction was higher, and the concentration of sulphate and $\mathrm{BC}$ was lower, compared to other studies of Arctic Haze (Quinn et al., 2007; Yamanouchi et al., 2005). Furthermore, given the data from the Zeppelin Station, the mean value of $\mathrm{BC}$ concentration measured by $\mathrm{AE}-31$ Aethalometer for 2005-2014 spring seasons equal to $43.6 \mathrm{ng} / \mathrm{m}^{3}$, but for 2014 only $32.7 \mathrm{ng} / \mathrm{m}^{3}$. This fact can prove that 2014 was generally a clean year in the European Arctic, with decreased anthropogenic or long-range fraction of the aerosol, but not the sea-salt.

Results of about 3 week observations of the single scattering properties in the Longyearbyen indicate a significant impact of the local anthropogenic emission. However, the temporal variability in scale of days shows similar patterns to data from Ny-Ålesund. Diurnal cycle of the scattering coefficient as well as the absorption coefficient imply emission activity between 05:00 and 21:00 UTC. The values measured during night time are close to Ny-Ålesund levels. Thus, the pollution concentration returns to the background value after reduction of local traffic emission. The impact of local emission is significant because the day time maximum is about 3 times larger than the background night values for scattering and absorption coefficients. In case of $\mathrm{Ny}-$ Ålesund the diurnal variability of the single scattering properties at the surface was not observed.

Optical remote sensing instruments as Lidar and photometer see

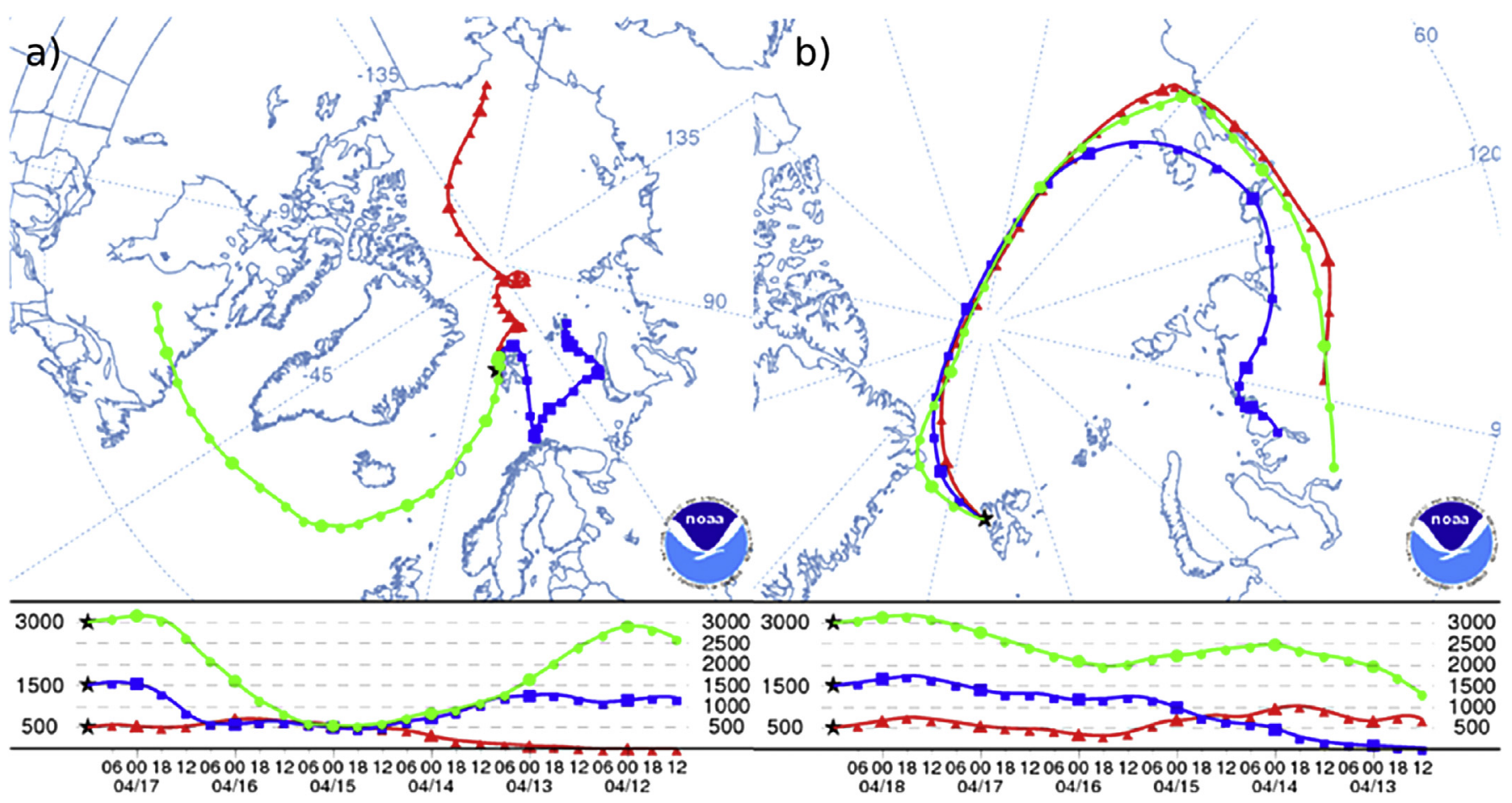

Fig. 15. $144 \mathrm{~h}$ back trajectories obtained from NOAA HYSPLIT model generated by means of NCEP reanalysis for (a) 17.04.2014 12:00 UTC and (b) 18.04.2014 12:00 UTC. 


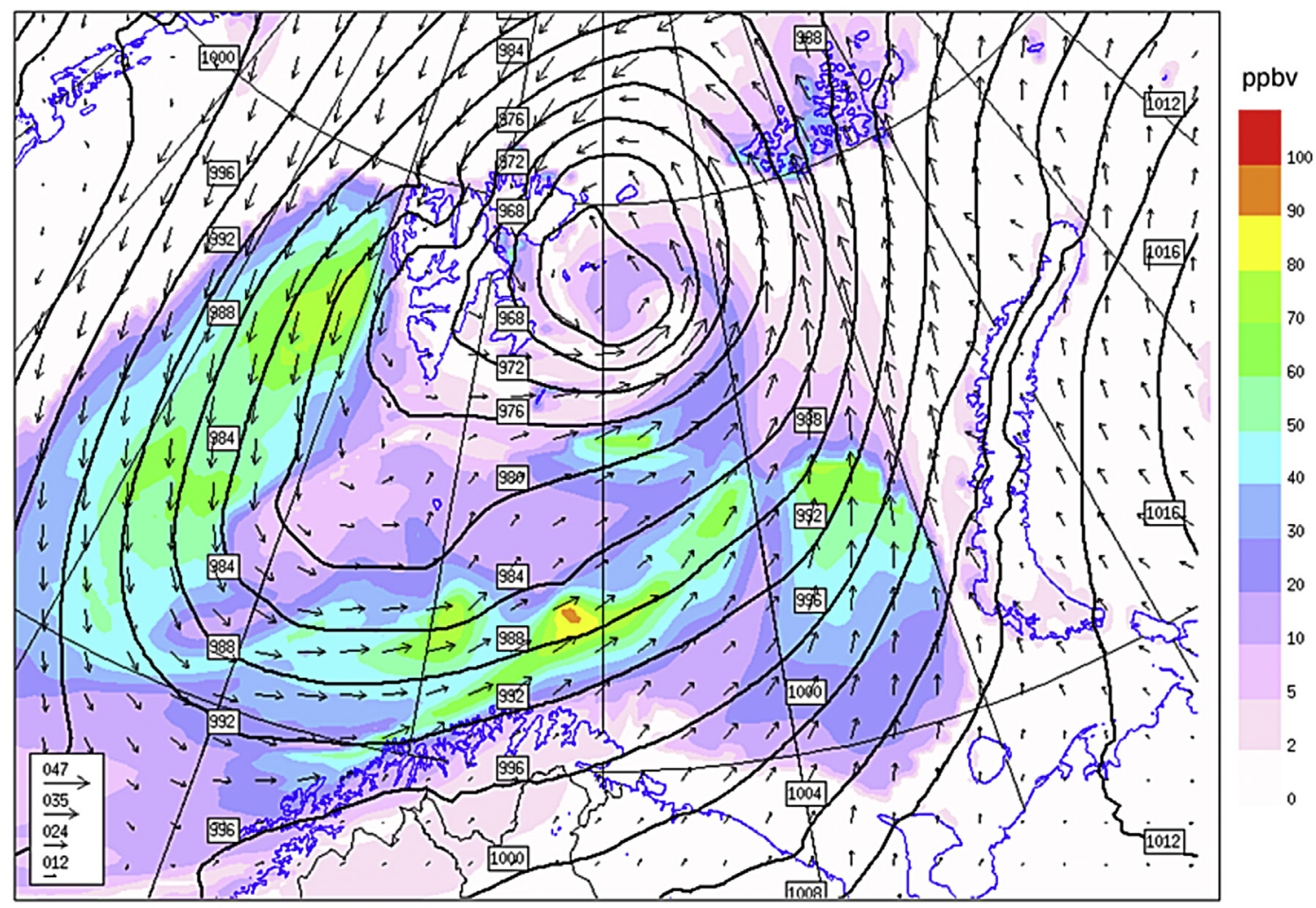

Fig. 16. Sea-salt mixing ratio [ppbv], mean sea level pressure [hPa] and wind speed [knots] on 17th of Apr 08:00 UTC

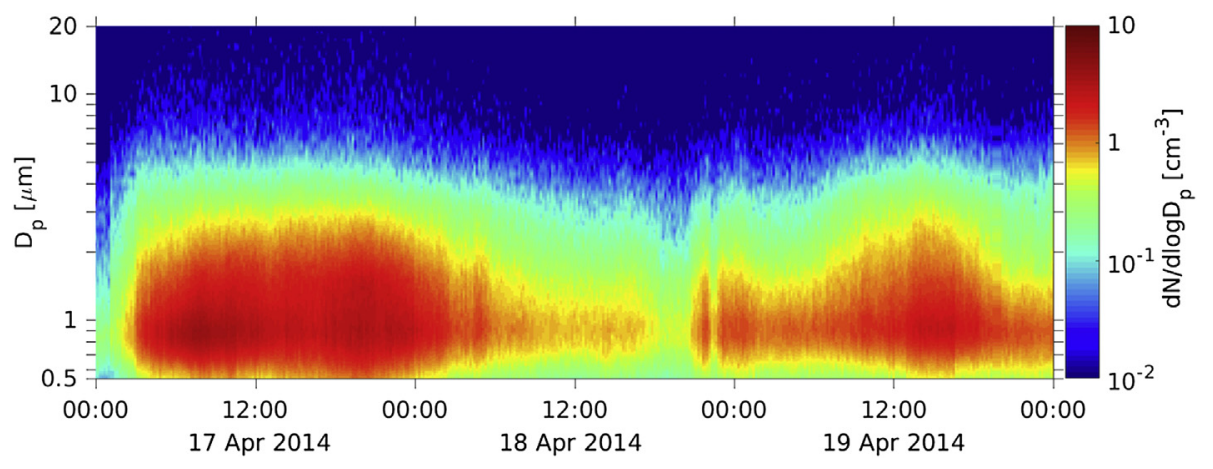

Fig. 17. Variability of aerosol number size distribution in Ny-Ålesund during 17-19th Apr 2014.

Table 4

Concentration of $\mathrm{Na}^{+}$as well as $\mathrm{nssSO}_{4}^{2-}$ particles in $\mathrm{Ny}-$ Ålesund during 16-19th Apr 2014.

\begin{tabular}{|c|c|c|c|c|}
\hline & $<1.0 \mu \mathrm{m}\left[\mathrm{ng} / \mathrm{m}^{3}\right]$ & $2.0-2.5 \mu \mathrm{m}\left[\mathrm{ng} / \mathrm{m}^{3}\right]$ & $2.5-10 \mu \mathrm{m}\left[\mathrm{ng} / \mathrm{m}^{3}\right]$ & $>10 \mu \mathrm{m}\left[\mathrm{ng} / \mathrm{m}^{3}\right]$ \\
\hline $\mathrm{Na}^{+}$ & 154.2 & 141.1 & 89.7 & 14.4 \\
\hline $\mathrm{nssSO}_{4}^{2}-$ & 485.2 & 84.2 & 28.6 & 5.6 \\
\hline
\end{tabular}

generally a higher extinction than derived by ground-based in-situ instruments. A similar result for $\mathrm{Ny}-$ Ålesund, even considering careful coinciding matches of the observed air volume, has recently been found by Tesche et al. (2014). This can be related to a hygroscopicity of particles as observed by Zieger et al. (2010), or due to peculiarities of the aerosol phase function. However this issue is beyond the scope of this paper and requires more investigation. In paper 2 more Lidar specific aerosol properties will be presented.

\section{Acknowledgements}

The research leading to these results has received funding from the Polish-Norwegian Research Programme operated by the National Centre for Research and Development under the Norwegian Financial Mechanism 2009-2014 in the frame of Project Contract No Pol-Nor/196911/38/2013. We acknowledge Brent Holben and Piotr Sobolewski for the use of the data from the Hornsund AERONET station. 


\section{References}

Anderson, T.L., Covert, D.S., Marshall, S.F., Laucks, M.L., Charlson, R.J., Waggoner, A.P., Ogren, J.A., Caldow, R., Holm, R.L., Quant, F.R., Sem, G.J., Wiedensohler, A., Ahlquist, N.A., Bates, T.S., 1996. Performance characteristics of a high-sensitivity, three-wavelength, total scatter/backscatter nephelometer. J. Atmos. Ocean. Technol. 13, 967-986.

Anderson, T.L., Ogren, J.A., 1998. Determining aerosol radiative properties using the TSI 3563 integrating nephelometer. Aerosol Sci. Tech. 29, 57-69.

Ångstrom, A., 1929. On the atmospheric transmission of Sun radiation and on dust in the air. Geogr. Ann. 11, 156-166.

Ansmann, A., Wandinger, U., Riebesell, M., Weitkamp, C., Michaelis, W., 1992. Independent measurement of extinction and backscatter profiles in cirrus clouds by using a combined Raman elastic-backscatter Lidar. Appl. Opt. 31, 7113-7131.

Arnott, W.P., Hamasha, K., Moosmüller, H., Sheridan, P.J., Ogren, J.A., 2005. Towards aerosol light-absorption measurements with a 7-Wavelenghth aethalometer: evaluation with a photoacoustic instrument and 3-Wavelength nephelometer. Aerosol Sci. Technol. 39, 17-29.

Bazzano, A., Ardini, F., Becagli, S., Traversi, R., Udisti, R., Cappelleti, D., Grotti, M., 2015. Source assessment of atmospheric lead measured at Ny-Ålesund. Svalbard. Atmos. Environ. 113 (2015), 20-26.

Becagli, S., Ghedini, C., Peeters, S., Rottiers, A., Traversi, R., Udisti, R., Chiari, M., Jalba, A., Despiau, S., Dayan, U., Temara, A., 2011. MBAS (methylene blue active substances) and LAS (linear alkylbenzene sulphonates) in mediterranean coastal aerosols: sources and transport processes. Atmos. Environ. 45, 6788-6801.

Behrendt, A., Nakamura, T., 2002. Calculation of the calibration constant of polarization Lidar and its dependency on atmospheric temperature. Opt. Express 10, 805-817.

Bowen, H.J.M., 1979. Environmental Chemistry of the Elements. Academic Press, London.

Draxler, R.R. Hess, G.D., 1998. An overview of the HYSPLIT 4 modeling system of trajectories, dispersion, and deposition. Aust. Meteor. Mag. 47, 295-308.

Engvall, A.-C., Krejci, R., Ström, J., Treffeisen, R., Scheele, R., Hermansen, O., Paatero, J., 2008. Changes in aerosol properties during spring-summer period in the Arctic troposphere. Atm. Chem. Phys. 8, 445-462.

Gong, S.L., Barrie, L.A., Blanchet, J.-P., von Salzen, K., Lohmann, U., Lesins, G., Spacek, L., Zhang, L.M., Girard, E., Lin, H., Leaitch, R., Leighton, H., Chylek, P., Huang, P., 2003. A size-segregated simulation of atmospheric aerosol processes for climate and air-quality models 1: module development. J. Geophys. Res. Atmos. 108 http://dx.doi.org/10.1029/2001JD002002.

Guo, L., Ping, C.-L., Macdonald, R.W., 2007. Mobilization pathways of organic carbon from permafrost to Arctic rivers in a changing climate. Geophys. Res. Lett. 34 http://dx.doi.org/10.1029/2007GL030689.

Graversen, R.G., Mauritsen, T., Tjernstrom, M., Kallén, E., Svensson, G., 2008. Vertical structure of recent arctic warming. Nature 451, 53-56. http://dx.doi.org/ 10.1038/nature06502.

Hassol, S.J., 2005. ACIA, Impacts of a Warming Arctic, Arctic Climate Impact Assessment. Cambridge University Press., New York.

Heintzenberg, J., Hansson, H.C., Lannefors, H., 1981. The chemical composition of Arctic haze at Ny-Ålesund, Spitsbergen. Tellus 33, 162-171. http://dx.doi.org/ $10.1111 / \mathrm{j} .2153-3490.1981 . t b 01741$.

Herber, A., Thomason, L.W., Gernandt, H., Leiterer, U., Nagel, D., Schulz, K.-H. Kaptur, J., Albrecht, T., Notholt, J., 2002. Continuous day and night aerosol optical depth observations in the Arctic between 1991 and 1999. J. Geophys. Res. 107, 1-14. http://dx.doi.org/10.1029/2001JD000536.

Hoffmann, A., Ritter, C., Neuber, R., Beninga, I., Schmidt, J., 2010. A redesigned Raman lidar for cloud and aerosol profiling. In: The Arctic. ILRC 25. St. Petersburg, S01P-07.

Hogrefe, O., Lala, G.G., Frank, B.P., Schwab, J.J., Demerjian, K.L., 2006. Field evaluation of a TSI 3034 scanning mobility particle sizer in New York city: winter 2004 intensive campaign. Aerosol Sci. Technol. 40, 753-762. http://dx.doi.org/ $10.1080 / 02786820600721846$.

Holben, B.N., Eck, T.F., Slutsker, I., Tanré, D., Buis, J.P., Setzer, A., Vermote, E.F., Reagan, J.A., Kaufman, Y.J., Nakajima, T., Lavenu, F., Jankowiak, I., Smirnov, A., 1998. AERONET - a federated instrument network and data archive for aerosol characterization. Rem. Sens, Environ. 66, 1-16.

Kaminski, J.W., Neary, L., Struzewska, J., McConnell, J.C., Lupu, A., Jarosz, J., Toyota, K., Gong, S.L., Côté, J., Liu, X., Chance, K., Richter, A., 2008. GEM-AQ an on-line global multiscale chemical weather modelling system: model description and evaluation of gas phase chemistry processes. Atmos. Chem. Phys. 8, 3255-3281.

Klett, J.D., 1981. Stable analytical inversion solution for processing lidar returns. Appl. Opt. 20, 211-220.

Klimont, Z., Kupiainen, K., Heyes, C., Cofala, J., Rafaj, P., Höglund-Isaksson, L., Borken, J., Schöpp, W., Winiwarter, W., Purohit, P., Bertok, I., Sander, R., 2013. ECLIPSE V4a: Global Emission Data Set Developed with the GAINS Model for the Period 2005 to 2050: Key Features and Principal Data Sources, 8. International Institute for Applied Systems Analysis (IIASA), Laxenburg, Austria.

Kok, G., Walker, J.W., Arnott, W.P., Arnold, I.J., Keady, P.B., 2010. Photoacoustic Extinctiometer (PAX): a New Instrument for Measurement of Climate-relevant Optical Properties of Aerosols. American Association for Aerosol Research, Oregon Convention Center, Portland, Oregon, USA.

Marconi, M., Sferlazzo, D.M., Becagli, S., Bommarito, C., Calzolai, G., Chiari, M., di Sarra, A., Ghedini, C., Gómez-Amo, J.L., Lucarelli, F., Meloni, D., Monteleone, F.,
Nava, S., Pace, G., Piacentino, S., Rugi, F., Severi, M., Traversi, R., Udisti, R., 2014 Saharan dust aerosol over the central Mediterranean Sea: PM $_{10}$ chemical composition and concentration versus optical columnar measurements. Atmos. Chem. Phys. 14, 2039-2054. http://dx.doi.org/10.5194/acp-14-2039-2014.

Maturilli, M., Herber, A., König-Langlo, G., 2013. Climatology and time series of surface meteorology in Ny $\neg$ Ålesund. Svalbard. Earth Syst. Sci. Data 5, 155-163. http://dx.doi.org/10.5194/essd-5-155-2013.

Mazzola, M., Stone, R.S., Herber, A., Tomasi, C., Lupi, A., Vitale, V., Lanconelli, C. Toledano, C., Cachorro, V.E., O'Neill, N.T., Shiobara, M., Aaltonen, V., Stebel, K. Zielinski, T., Petelski, T., Ortiz de Galisteo, J.P., Torres, B., Berjon, A., Goloub, P. Li, Z., Blarel, L., Abboudm, I., Cuevas, E., Stock, M., Schulz, K.-H., Virkkula, A. 2012. Evaluation of sun photometer capabilities for retrievals of aerosol optical depth at high latitudes: the POLAR-AOD intercomparison campaigns. Atmos. Environ. 52, 4-17.

Morganti, A., Becagli, S., Castellano, E., Severi, M., Traversi, R., Udisti, R., 2007. An improved flow analysis-ion chromatography method for determination of cationic and anionic species at trace levels in AntArctic ice cores. Anal. Chim. Acta 603, 190-198.

Morys, M., Mims III, F.M., Hagerup, S., Anderson, S.E., Baker, A., Kia, J., Walkup, T. 2001. Design, calibration, and performance of MICROTOPS II handheld ozone monitor and Sun photometer. J. Geophys. Res. 106, 14573-14582.

Müller, T., Laborde, M., Kassell, G., Wiedensohler, A., 2011. Design and performance of a three-wavelength LED-based total scatter and backscatter integrating nephelometer. Atmos. Meas. Tech. 4, 1291-1303. http://dx.doi.org/10.5194 amt-4-1291-2011.

Nozaki, Y., 1997. A Fresh Look at Element Distribution in the North Pacific. http:// www.agu.org/eos elec/97025e.html.

Parkinson, C.L., Cavalieri, D.J., 2012. Arctic sea ice variability and trends, 1979-2010. J. Geophys. Res. Oceans 113.

Peters, T.M., Leith, D., 2003. Concentration measurement and counting efficiency of the aerodynamic particle sizer 3321. J. Aerosol Sci. 34, 627-634. http:/ dx.doi.org/10.1016/S0021-8502(03)00030-2.

Quinn, P.K., Shaw, G., Andrews, E., Dutton, E.G., Ruoho-Airola, T., Gong, S.L., 2007. Arctic haze: current trends and knowledge gaps. Tellus 59, 99-114. http:// dx.doi.org/10.1111/j.1600-0889.2006.00238x.

Rozwadowska, A., Zielinski, T., Petelski, T., Sobolewski, P., 2010. Cluster analysis of the impact of air back trajectories on aerosol optical properties at Hornsund, Spitsbergen. Atmos. Chem. Phys. 10, 877-893.

Simon, X., Duquenne, P., 2013. Feasibility of generating peaks of bioaerosols for laboratory experiments. Aerosol Air Qual. Res. 13, 877-886. http://dx.doi.org/ 10.4209 /aaqr 2012.12.0340.

Struzewska, J., Zdunek, M., Kaminski, J.W., Łobocki, L., Porebska, M., Jefimow, M., Gawuc, L., 2015. Evaluation of the GEM-AQ model in the context of the AQMEI Phase 1 project. Atmos. Chem. Phys. 15, 3971-3990. http://dx.doi.org/10.5194/ acp-15-3971-2015.

Stone, R.S., Sharma, S., Herber, A., Eleftheriadis, K., Nelson, D.W., 2014. A characterization of Arctic aerosols on the basis of aerosol optical depth and black carbon measurements. Elem. Sci. Anth. 2 doi: 10.12952.

Tang, I.N., Munkelwitz, H.R., 1994. Aerosol phase transformation and growth in the atmosphere. J. Appl. Meteor. 33, 791-796. http://dx.doi.org/10.1175 1520-0450.

Tang, I.N., 1996. Chemical and size effects of hygroscopic aerosols on light scattering coefficients. J. Geophys. Res. 101, 19245-19250. http://dx.doi.org/10.1029/ 96JD03003.

Tesche, M., Zieger, P., Rastak, N., Charlson, R.J., Glantz, P., Tunved, P., Hansson, H.-C., 2014. Reconciling aerosol light extinction measurements from spaceborne Lidar observations and in situ measurements in the Arctic. Atmos. Chem. Phys. 14 7869-7882. http://dx.doi.org/10.5194/acp-14-7869-2014.

Tomasi, C., Lupi, A., Mazzola, M., Stone, R., Dutton, E., Herber, A., Radionov, V., Holben, B., Sorokin, M., Sakerin, S., Terpugova, S., Sobolewski, P., Lanconelli, C., Petkov, B., Busetto, M., Vitale, V., 2012. An update on Polar aerosol optical properties using POLAR-AOD and other measurements performed during the International Polar Year. Atmos. Environ. 52, 29-47.

Tomasi, C., Kokhanovsky, A., Lupi, A., Ritter, C., Smirnov, A., O’Neill, N., Stone, R., Holben, B., Nyeki, S., Wehrli, C., Wehrli, C., Stohl, A., Mazzola, M., Lanconelli, C. Vitale, V., Stebel, K., Aaltonen, V., Leeuw, G., Rodriguez, E., Herber, A Radionov, V., Zielinski, T., Petelski, T., Sakerin, S., Kabanov, D., Xue, Y., Mei, L., Istomina, L., Wagener, R., McArthur, B., Sobolewski, P., Kivi, R., Courcoux, Y., Larouche, P., Broccardo, S., Piketh, S., 2015. Aerosol remote sensing in polar regions. Earth-Sci. Rev. 140, 108-157.

Yamanouchi, T., Treffeisen, R., Herber, A., Shiobara, M., Yamagata, S., Hara, K., Sato, K., Yabuki, M., Tomikawa, Y., Rinke, A., Neuber, R., Schumacher, R. Kriews, M., Stroem, J., Schrems, O., Gernandt, H., 2005. Arctic study of tropospheric aerosol and radiation (ASTAR) 2000: arctic haze case study. Tellus 57b, 141-152. http://dx.doi.org/10.1111/j.1600-0889.2005.00140.x.

Zábori, J., Krejci, R., Ström, J., Vaattovaara, P., Ekman, A.M.L., Mårtensson, E.M., Nilsson, E.D., 2012. Comparison between summertime and wintertime Arctic Ocean primary marine aerosol properties. Atmos. Chem. Phys. Discuss. 12, 31153-31186.

Zieger, P., Fierz-Schmidhauser, R., Gysel, M., Ström, J., Henne, S., Yttri, K.E. Baltensperger, U., Weingartner, E., 2010. Effects of relative humidity on aerosol light scattering in the Arctic. Atmos. Chem. Phys. 10, 3875-3890.

Zieger, P., Fierz-Schmidhauser, R., Weingartner, E., Baltensperger, U., 2013. Effects of relative humidity on aerosol light scattering: results from different European sites. Atmos. Chem. Phys. 13, 10609-10631. 